Golden Gate University School of Law GGU Law Digital Commons

2011

\title{
A Unique Bench, A Common Code: Evaluating Judicial Ethics in Juvenile Court
}

Michele Benedetto Neitz

Golden Gate University School of Law, mneitz@ggu.edu

Follow this and additional works at: http://digitalcommons.law.ggu.edu/pubs

Part of the Judges Commons, and the Juvenile Law Commons

\section{Recommended Citation}

24 Georgetown J. of Legal Ethics 97 (2011)

This Article is brought to you for free and open access by the Faculty Scholarship at GGU Law Digital Commons. It has been accepted for inclusion in Publications by an authorized administrator of GGU Law Digital Commons. For more information, please contact jischer@ggu.edu. 


\title{
A Unique Bench, A Common Code: Evaluating Judicial Ethics in Juvenile Court
}

\author{
Michele Benedetto Neitz*
}

\begin{abstract}
Recent cases involving ethical scandals on the juvenile court bench have caught the interest of legal scholars, judges, practitioners, and the public. This article proposes a new theoretical framework for assessing these problems and articulates a series of vital ethical reforms.

Despite their distinct role in an atypical court, juvenile court judges are not subject to unique ethical standards. Most jurisdictions have adopted the ABA Model Code of Judicial Conduct as the ethical code guiding juvenile court judges. However, this Model Code, intended to apply to any person in a decision-making capacity, was created for a more conventional type of judging than is expected from a juvenile court judge. Because these standards do not address the exceptional roles and challenges facing juvenile court judges, the potential for ethical violations and injustice is significant.

This article therefore recommends innovative textual revisions designed to provide much-needed ethical guidance to juvenile court judges in three critical areas: (1) ex parte communications; (2) competence; and (3) demeanor and decorum. The implementation of ethical guidelines tailored for this specialized court will remedy an existing flaw in the scheme of judicial ethics, while reinforcing judges' abilities to determine the best outcomes for troubled youth.
\end{abstract}

\section{INTRODUCTION}

Fourteen-year-old Tommy was arrested in 2007 for stealing loose change from unlocked cars. ${ }^{1}$ The arresting police officer told Tommy's mother that he would likely receive probation for this minor offense. When two lawyers consulted by Tommy's mother confirmed that probation was the likely outcome of Tommy's

\footnotetext{
* Associate Professor, Golden Gate University School of Law, San Francisco, California. J.D., New York University School of Law. The author once worked as a law clerk for the Legal Aid Society in New York City juvenile courts. I am grateful to Professor Deborah Rhode and Professor Sarah Cravens for their thoughtful feedback on earlier drafts. I also thank my colleagues at Golden Gate University School of Law for their support, particularly Eric Christiansen and Rachel Van Cleave, and research assistants Ellen Jenkins and Jaimie Bombard. (C) 2010, Michele Benedetto Neitz.

1. Although the name has been changed, this case study was drawn from Plaintiffs' Amended Class Action Complaint, H.T. vs. Ciavarella, No. 3:09-cv-00357-ARC (M.D. Pa. 2009), available at http://www.jlc.org/files/ luzernecounty/Luzerne_complaint_Amended_04-23-09Final.pdf.
} 
juvenile court proceedings, she did not hire an attorney to represent her son.

During a three-minute hearing in which Tommy was not represented by an attorney, juvenile court Judge Mark A. Ciavarella allegedly did not explain to Tommy the significance of giving up the right to counsel and other legal rights by pleading guilty. When Tommy pled guilty, he was ordered to spend twelve months at a residential school. He was not assigned a grade level and was placed in pre-GED classes. When he finally returned home, Tommy was held back a grade; his resulting anxiety prevented him from later attending a traditional school.

A twelve-month sentence for such a minor offense would be an astonishing result in adult criminal court. However, Tommy's case was only one of many juvenile delinquency cases adjudicated by Judge Ciavarella in Luzerne County, Pennsylvania, in which disproportionate sentences were imposed. Judge Ciavarella regularly sent one in four juvenile delinquents to detention facilities in a jurisdiction where the usual rate for juveniles was one in ten. ${ }^{2}$

In early 2009, the mystery of Judge Ciavarella's behavior on the bench was solved: Judge Ciavarella and his co-conspirator, Judge Michael T. Conahan, received millions of dollars from private detention facilities in exchange for placing youth in those facilities. ${ }^{3}$ Both judges pled guilty and were sentenced to eighty-seven months in prison. ${ }^{4}$ In March 2009, the Supreme Court of Pennsylvania ordered the records of hundreds of youth sentenced by Judge Ciavarella to be expunged. ${ }^{5}$

This tale of judicial corruption in Pennsylvania's juvenile courts brought significant media attention to the expansive discretionary powers of judges in juvenile court. It is certainly an extreme example of unethical judicial behavior. Many, if not most, juvenile court judges seek to perform their duties in an ethical manner with great respect for the litigants in their courtrooms. Nevertheless, juvenile court judges traditionally operate in a closed environment with minimal public scrutiny. ${ }^{6}$ While the concept of judges exchanging juvenile court detention

2. John Schwartz, Clean Slates for Youth Sentenced Fraudulently, N.Y. TimeS, Mar. 27, 2009, available at http://www.nytimes.com/2009/03/27/us/27judges.html. Youth advocacy groups often complained about the unusually harsh nature of Judge Ciavarella's adjudications. See Ian Urbina \& Sean D. Hamill, Judges Plead Guilty in Scheme to Jail Youth for Profit, N.Y. TIMES, Feb. 12, 2009, available at http://www.nytimes.com/2009/ 02/13/us/13judge.html.

3. Urbina \& Hamill, supra note 2.

4. Dave Janoski, Disgraced Judge Ciavarella Calls Powell “Liar,” Times TriB. (Scranton, Pa.), July 3, 2009, available at http://thetimes-tribune.com/news/disgraced-judge-ciavarella-calls-powell-liar-1.102873?lo calLinksEnabled $=$ false.

5. See Schwartz, supra note 2.

6. Confidentiality laws prevent information about most juvenile court cases from reaching the public, and it is therefore "critical that the juvenile court judge ensure that information about the juvenile court system is made available to the public. Only in this way will the public receive a balanced view of the work of the juvenile court and not rely solely on the spectacular headlines which appear at regular intervals." Judge Leonard P. Edwards, The Juvenile Court and the Role of the Juvenile Court Judge, 43 Juv. \& FAм. Ст. J., no. 2, 1992 at 29. 
placements for cash is likely an isolated incident, this case highlights the need for a renewed focus on judicial ethics in juvenile court.

Juvenile court was designed over 100 years ago as a mechanism to improve outcomes for delinquent youth. Its founders emphasized the rehabilitative purpose of this special court; youthful offenders were to be treated, not punished. ${ }^{7}$ In the modern era, juvenile courts exist in every jurisdiction. These courts differ substantially from criminal courts involving the adjudication of adult offenders. In addition to adjudicating individual cases, juvenile court judges serve society as a whole. Lack of constructive early intervention in juvenile delinquency cases can send youth down a path of longtime criminal conduct, which has enormous costs for society. ${ }^{8}$

Despite their unique role in a unique court, juvenile court judges are not subject to unique ethical standards. Rather, juvenile court judges are held to the same standards intended to govern civil and criminal courts. These standards do not address the special problems facing juvenile court judges. To address the lack of guidance for juvenile court, state legislatures, individual courts, and advocacy groups have filled in the gap with non-binding training materials and guidelines specifically designed for juvenile court judges. Notwithstanding this apparent understanding that juvenile court involves concerns that are not present in adult court, there exists no uniform standard of conduct for juvenile court judges. The failure of the ABA Code of Judicial Conduct to address the unique needs of juvenile court judges has yet to be considered in academic literature.

This Article proposes the creation of critical provisions in the code of judicial ethics to be applied to juvenile court. Although a complete examination of juvenile court structure and disciplinary processes is beyond the scope of this piece, the recommendations that follow are a necessary first step toward ensuring both ethical guidance and accountability in juvenile court. Acknowledging that the term "juvenile court" can encompass family court proceedings, child custody proceedings, and other areas, this article's focus will be juvenile delinquency proceedings.

Part II traces the history of the juvenile court, including a review of the Supreme Court's constitutional framework for juvenile justice. Although juvenile courts are currently moving toward a more punitive and less rehabilitative model, the purpose, procedures, and outcomes of juvenile court remain different than adult criminal court. Part III therefore considers the specialized role of juvenile court, with particular attention paid to the structure of the court and the roles of its judges. Part III also explores the distinctive challenges faced by juvenile court

7. See discussion infra Part II.A; see also Janet E. Ainsworth, Re-Imagining Childhood and Reconstructing the Legal Order: The Case for Abolishing the Juvenile Court, 69 N.C. L. REv. 1083, 1098 (1991).

8. Mark A. Cohen \& Alex R. Piquero, New Evidence on the Monetary Value of Saving a High Risk Youth, 25 J. Quantitative Criminology, No. 1, at 25, 47 (2009) (the "typical career criminal" imposes costs of approximately $\$ 230,000$ through age 14 ; over a lifetime, those costs aggregate to $\$ 5.7$ million per criminal). 
judges.

Since nearly all states have substantially adopted the ABA Code of Judicial Conduct as the ethical code applicable to juvenile court judges, Part IV examines the suitability of applying this generic code of conduct to judges in these specialized courts. A review of the history of judicial ethics demonstrates that these standards were created for a more conventional type of judging than is expected from a juvenile court judge.

Accordingly, Part V recommends revision of the ABA Code of Judicial Conduct to reflect the special needs of juvenile court. As a starting point, this article offers provisions to be included in a revised Code of Judicial Conduct for juvenile court judges in three areas of particular importance: (1) ex parte communications; (2) judicial competence; and (3) bias, judicial demeanor, and decorum. These provisions will address grievous circumstances, such as those in Judge Ciavarella's courtroom, as well as provide guidance for ethical judges. Moreover, implementation of a revised code of conduct for juvenile court judges will increase public confidence in this atypical court.

\section{The Evolving History of Juvenile Court}

\section{A. THE CREATION OF A UNIQUE COURT FOR CHILDREN}

The history of juvenile courts is well-documented. ${ }^{9}$ The juvenile court movement began during the "Progressive Era," the period from 1880 to 1920 characterized by major social and structural changes in the United States. ${ }^{10}$ The advent of industrialization and urbanization in the mid-nineteenth century, coinciding with the breakdown of the traditional home and domestic life, raised concern about youth who were "no longer governed by the traditional authority of the family or other social institutions" and instead "took to the streets" for work and entertainment. ${ }^{11}$

The motivations of the Progressive reformers who created juvenile courts are somewhat conflicting. Middle-class and wealthy Progressives expressed concern for the welfare of youth and fought for the salvation of children of broken homes. ${ }^{12}$ At the same time, the social order required control of possible criminals

9. See generally, e.g., BARRy Krisberg \& JAmes F. Austin, ReinVEnting Juvenile Justice (1993); Solomon J. Greene, Vicious Streets: The Crisis of the Industrial City and the Invention of Juvenile Justice, 15 YALE J.L. \& Human. 135 (2003); Barry C. Feld, Abolish the Juvenile Court: Youthfulness, Criminal Responsibility, and Sentencing Policy, 88 J. CRIM. L. \& CRIMINOLOGY 68 (1997).

10. KRISBERG \& AUSTIN, supra note 9, at 27. The reformists of this era implemented significant social reforms, including the public defender movement, the increased use of mental and I.Q. testing, and the "scientific study of crime." Id.

11. Greene, supra note 9, at 136.

12. See Krisberg \& Austin, supra note 9, at 30. 
who presented a potential threat to citizens and their own children. ${ }^{13}$ The Progressives thus sought to construct a system which would rehabilitate delinquent youth while preventing social unrest. ${ }^{14}$

The reformers turned to the philosophy of parens patrie, giving the state the authority to act as a parent. ${ }^{15}$ Underlying this philosophy is the notion that paternal action, rather than penal action, is the proper response to the problems of juvenile crime and "urban crisis." ${ }^{16}$ Accordingly, Illinois created the first juvenile court in 1899 to address cases of delinquent, dependent, and neglected children. ${ }^{17}$ The court retained the authority to either place children in orphanages or foster homes, or place children on probation. ${ }^{18}$ Unpaid probation officers, who were initially middle-class female reformers, assisted judges in supervising youth. ${ }^{19}$

Within ten years of the creation of juvenile court in Illinois, ten states had established similar courts. By 1925, all but two states had launched "specialized courts for children." ${ }^{20}$ These courts were commended for providing for the "salvation" of children by "bringing [a child] into one of the courts of the state ... for the purpose of subjecting it to the state's guardianship and protection." 21 Rather than viewing a court case in terms of resolving the "guilt" or "innocence" of a child, reformers wanted a child in juvenile court "to feel that he is the object of [the state's] care and solicitude, not that he was under arrest or on trial." 22 Children were to be "treated and rehabilitated" through clinical, not punitive, procedures. ${ }^{23}$

Yet because the adult penal system was "never completely off-limits for children," the risk of punishment was always a possibility. ${ }^{24}$ In this way, societal fear of juveniles committing crimes undermined the rehabilitative nature of juvenile court. ${ }^{25}$ As discussed below, this ambivalent approach to juvenile court is still present today: A tension exists between the desire to rehabilitate and the

13. Feld, supra note 9, at 93 . The resulting juvenile court movement, combining "social welfare and penal social control," has been criticized as the embodiment of "an inherent conceptual flaw and an innate contradiction." Id.

14. See Krisberg \& Austin, supra note 9, at 29.

15. Edwards, supra note 6, at 4.

16. Greene, supra note 9, at 143.

17. KRISBERG \& AUSTIN, supra note 9 , at 30 .

18. $I d$.

19. Greene, supra note 9, at 148; see also KRISBERG \& Austin, supra note 9, at 30.

20. KRISBERG \& Austin, supra note 9 , at 30.

21. Id. (citing Commonwealth v. Fisher, $213 \mathrm{~Pa} .48$ (Pa. 1905) (internal citations omitted)).

22. In re Gault, 387 U.S. 1, 15 (1967) (citing Julian Mack, The Juvenile Court, 23 HARv. L. Rev. 104, 119-20 (1909) (reformers "believed that society's role was not to ascertain whether the child was 'guilty' or 'innocent,' but '[w]hat is he, how has he become what he is, and what had best be done in his interest and in the interest of the state to save him from a downward career."')).

23. In re Gault, 387 U.S. at 16.

24. Judge Jay D. Blitzman, Gault's Promise, 9 BARry L. Rev. 67, 74 (2007) (citing Sanford J. Fox, The Early History of the Court, 6 FUTURE OF CHILD 29 (1996)).

25. See id. 
desire to punish. Moreover, as reformers celebrated this "new age" of treatment of children, they also reinforced the concept that social problems such as delinquency could be solved through individual cases without broader social reforms. ${ }^{26}$

As with every case-by-case analysis, however, outcomes in juvenile court were heavily dependent on the perspectives of individual decision-makers. The "hallmark" of juvenile court was the individual case disposition, designed to address the needs of the juvenile. ${ }^{27}$ With the concept of a jury trial deemed "irrelevant" to the central issue at hand, namely how best to treat but not punish a child, the role of the juvenile court judge became increasingly important. ${ }^{28}$ Consequently, "judges were given almost limitless discretion ... to facilitate whatever the judge thought would "cure' the youth." 29

However, critics of juvenile court condemned the "seemingly unlimited discretion" of juvenile court judges. ${ }^{30}$ Specifically, they claimed that without procedural due process and other constitutional protections, juvenile court proceedings resulted in "arbitrary and capricious" judicial decisions. ${ }^{31}$ Advocates argued in response that juvenile court judges acted with compassion, and focused on rehabilitation and the "best interests" of the child. ${ }^{32}$ The debate over judicial discretion and constitutional criminal protections in juvenile court ultimately reached the Supreme Court in 1967.

\section{B. THE SUPREME COURT'S CONSTITUTIONAL FRAMEWORK FOR JUVENILE COURT}

In its landmark holding in In re Gault, the United States Supreme Court modified the constitutional protections in juvenile court proceedings. ${ }^{33}$ Fifteenyear-old Gerald Francis Gault was picked up by the County Sheriff for making telephone calls of the "irritatingly offensive, adolescent, sex variety." ${ }^{34}$ His family was not notified that he was taken into custody. ${ }^{35}$ At a hearing before a juvenile court judge the next day, Gerald was not represented by an attorney. ${ }^{36}$

\footnotetext{
26. See Krisberg \& Austin, supra note 9, at 31-32; see also Feld, supra note 9, at 94-95 ("'Child-saving' satisfied humanitarian impulses without engendering more fundamental social change.").

27. See Ainsworth, supra note 7, at 1099.

28. See id. at 1101.

29. Id. at 1099 .

30. See Krisberg \& Austin, supra note 9, at 30.

31. Steven A. Drizin \& Greg Luloff, Are Juvenile Courts a Breeding Ground for Wrongful Convictions?, 34 N. Ky. L. REv. 257, 263 (2007).

32. Id. See generally Mack, supra note 22, at 120 ("The child who must be brought into court should, of course, be made to know that he is face to face with the power of the state, but he should at the same time, and more emphatically, be made to feel that he is the object of its care and solicitude.").

33. In re Gault, 387 U.S. 1 (1967).

34. Id. at 4 .

35. Id. at 5 .

36. Id.
} 
No transcript, recording, or other record of the proceedings was created, and Gerald was not able to confront his accuser. ${ }^{37}$ Using his discretion, the judge sentenced Gerald "as a juvenile delinquent" to the State Industrial School until age twenty-one. ${ }^{38}$

Because no appeal was allowed for Arizona juvenile cases, Gerald filed a habeas corpus petition. ${ }^{39}$ The United States Supreme Court granted certiorari to address the impact of the Fourteenth Amendment's Due Process Clause upon juvenile court proceedings. Although recognizing that "the highest motives and most enlightened impulses led to a peculiar system for juveniles," the Court raised concerns about the broad judicial discretion provided to juvenile court judges. ${ }^{40}$ Specifically, the Court noted that the history of juvenile court illustrated that "unbridled discretion, however benevolently motivated, is frequently a poor substitute for principle and procedure." ${ }^{41}$ Without adequate procedures, juveniles could be deprived of fundamental rights and denied due process. ${ }^{42}$

The Court thus took a new approach to juvenile court in Gault, initiating a "patchwork jurisprudence of juveniles' constitutional rights." ${ }^{43}$ The Court acknowledged the unique benefits of the juvenile system, but believed that the imposition of due process standards would not disrupt such benefits. ${ }^{44}$ Accordingly, the Court held that a juvenile in court proceedings is entitled to those rights that are necessary to fulfill the fundamental fairness guarantee of the Due Process Clause: the right to counsel, the right to confront and cross-examine witnesses, and the privilege against self-incrimination. ${ }^{45}$

The juvenile court judge in Gault used his judicial discretion to act like a judge in adult criminal court. In particular, he focused only on those aspects of Gault's case that would support his decision to impose a six-year sentence. The Supreme Court did not focus its opinion on judicial ethics, but instead imposed procedural protections designed to constrain judicial discretion. The Court observed that the

37. Id. at 5,7 .

38. Id. at 7-8. Of note, an adult penalized for the same conduct would have received a fine of $\$ 5$ to $\$ 50$, or imprisonment for not more than two months. Id. at 9-10.

39. Gault, 387 U.S. at 8.

40. Id. at 17-18.

41. Id. at 18. The Court further noted that "[t]he absence of substantive standards has not necessarily meant that children receive careful, compassionate, individualized treatment." Id.

42. Id. at 19 (quoting Paul S. Lehman, A Juvenile's Right to Counsel in a Delinquency Hearing, 17 Juv. Cт. JudGES J. 53, 54 (1966)).

43. Elisa Poncz, Rethinking Child Advocacy After Roper v. Simmons: "Kids are Just Different" and "Kids are Like Adults” Advocacy Strategies, 6 CARdozo PuB. L. PoL’y \& Ethics J. 273, 278 (2008).

44. Gault, 387 U.S. at 21-22. By way of example, the Court noted that the application of due process requirements would not interfere with the juvenile offender's classification as "delinquent" rather than "criminal." Id. at 23.

45. See id. at 1; see also Martin Guggenheim \& Randy Hertz, Reflections on Judges, Juries, and Justice: Ensuring the Fairness of Juvenile Delinquency Trials, 33 WAKE FoREST L. REv. 553, 558 (1998) (“[T]he Gault majority decreed that juveniles would enjoy only those constitutional rights necessary to implement the Due Process Clause's guarantee of 'fundamental fairness."'). 
"essential difference" between Gault's juvenile court proceeding and an adult criminal court proceeding is that "safeguards available to adults were discarded in Gerald's case." 46 Moreover, the facts of the Gault case demonstrate the consequence of unethical behavior on the part of judges.

For example, the Gault Court carefully considered the juvenile judge's testimony about his decision-making process. The Court clearly expected a juvenile court judge to make a "careful inquiry and judgment as to the possibility that the boy could be disciplined and dealt with at home, despite his previous transgressions." ${ }^{47}$ Yet, the juvenile court judge's testimony about Gault's juvenile court proceeding was "devoid of any meaningful discussion of this"; instead, the judge concentrated on the same points which would be at issue in an adult criminal court proceeding, such as Gault's probationary status. ${ }^{48}$

The juvenile court judge's failure to take into account all applicable evidence in Gault raises ethical concerns of judicial incompetence. ${ }^{49}$ As discussed in Part $\mathrm{V}$ (B), infra, competence is a critical component of judicial ethics. In addition, if Gault's juvenile court judge had focused more on true rehabilitation of this young offender, rather than punishment, the Supreme Court perhaps would not have been so concerned about juvenile court proceedings. Accordingly, this particular judge's unethical behavior, ignoring both evidence of a stable home and the rehabilitative purpose of juvenile court, is arguably responsible for the sweeping "due process revolution" imposed by the Supreme Court. ${ }^{50}$

With this decision, the Court moved juvenile court proceedings away from the "guardianship and protection" ideal ${ }^{51}$ and closer to the format used in "adversary criminal trials." 52 The shift did not go unnoticed; Justice Stewart warned in his Gault dissent that the Court's decision served to "convert a juvenile proceeding into a criminal prosecution." 53

Throughout the 1960s and 1970s, the Supreme Court continued to develop the application of constitutional rights_-while ignoring judicial ethics_-in relation to

\footnotetext{
46. Gault, 387 U.S. at 29.

47. Id. at 28 .

48. Id. at 28 n. 41 .

49. See discussion of judicial competence, infra Part V.B.

50. The term "revolution" is used often by scholars examining In re Gault. See Blitzman, supra note 24, at 69 ("Gault appeared to herald a due process revolution in juvenile law."); see also Perry Moriearty, Combating the Color-Coded Confinement of Kids: An Equal Protection Remedy, 32 N.Y.U. Rev. L. \& Soc. Change 285, 286 (2008) ("The so-called 'Due Process Revolution' of the 1960s led to the implementation of various constitutional safeguards that had the unintended effect of transforming juvenile court proceedings from informal, administrative hearings into full-blown prosecutions.").

51. KRISBERg \& Austin, supra note 9, at 30 (quoting Commonwealth v. Fisher, 62 A. 198 (Pa. 1905) (internal citations omitted)).

52. Gault, 387 U.S. at 78 (Stewart, J., dissenting).

53. Id. at 79 .
} 
juvenile court. ${ }^{54}$ Given the Court's concern in Gault about judicial discretion in juvenile court, and the resulting expansion of constitutional rights in the years following Gault, it would have been a natural progression for the Court to impose a jury trial requirement and remove judicial decision-making from such proceedings. However, the Court refused to do so in 1971 in McKeiver v. Pennsylvania. ${ }^{55}$

Joseph McKeiver, age sixteen, and Edward Terry, age fifteen, were separately charged with criminal violations of Pennsylvania law. ${ }^{56}$ Their lawyers' requests for jury trials were denied. ${ }^{57}$ Different juvenile court judges, determining that the youth were delinquent, denied their appeals. ${ }^{58}$

The Supreme Court granted certiorari on these cases as well as similar cases from North Carolina to address the issue of whether jury trials are constitutionally required in juvenile court. In a plurality opinion, the Court conceded that the "idealistic hopes" of the founders of juvenile court "have not been realized," and juvenile court judges often fell "far short of that stalwart, protective, and communicating figure the system envisaged." 59

Despite such disappointments, the Court found that imposing a jury trial would not remedy the "defects" in juvenile court and would not strengthen the fact-finding function ${ }^{60}$ Rather, the Court noted that a jury trial requirement would remake the juvenile court hearing into an adversary proceeding like criminal court, eroding informality and causing delay in what should be a "protective" court. ${ }^{61}$ Furthermore, mandating jury trials would impede states from experimenting on their own to improve their juvenile court systems. ${ }^{62}$ As a result, the Court allowed states to provide jury trials, but stopped short of requiring such action from all states. ${ }^{63}$

Some three decades later, approximately twenty percent of states required jury

54. See generally, e.g., Kent v. United States, 383 U.S. 541 (1966) (prior to Gault, the Court held a juvenile was entitled to hearing with counsel before waiver to adult criminal court); Breed v. Jones, 421 U.S. 519 (1975) (prohibition against double jeopardy prevents individual from being tried in both juvenile and adult criminal court for same offense); In re Winship, 397 U.S. 358 (1970) (constitutional safeguard of standard of proof beyond a reasonable doubt is required in delinquency proceeding).

55. McKeiver v. Pennsylvania, 403 U.S. 528 (1971).

56. Id. at 534-35.

57. Id. at 535 .

58. Id.

59. Id. at 543-44. To support this claim, the Court referenced a 1967 Presidential Task Force report finding that half of juvenile court judges had not obtained undergraduate degrees, a fifth had obtained no college education, and another fifth were not members of the bar. Id. at 544 n.4 (citing THE PRESIDENT's COMM'N ON Law Enforcement and Admin. of Justice, Task Force Report: Juvenile Delinquency and Youth Crime 7 (1967)).

60. McKeiver, 403 U.S. at 528.

61. Id. at 528-29.

62. Id. at 547 ("The States, indeed, must go forward.").

63. See Blitzman, supra note 24 , at 84 . 
trials in juvenile court. ${ }^{64}$ The discretion of the juvenile court judge is more powerful in those states that do not mandate jury trials. Repeating a theme heard in Gault, the McKeiver Court recognized the potential discrepancy inherent in a system affording broad discretion to judges. The Court expressed "an appreciation for the juvenile court judge who is devoted, sympathetic, and conscientious" while at the same time voiced concern about the judge who is "untrained and less than fully imbued with an understanding approach to the complex problems of childhood and adolescence." ${ }^{65}$ The fact that two such judges could simultaneously decide cases involving young lives-often within the same courthouse-is indeed cause for concern. ${ }^{66}$ Yet the Supreme Court's opinion in McKeiver, while quoting extensively from a 1967 Presidential Task Force report reciting the failures of juvenile court, neglected to even mention judicial ethics as a potential remedy for its problems. ${ }^{67}$ Instead, the Court used conclusory language to dismiss "abuses" in juvenile court as relating to "lack of resources and of dedication rather than to inherent unfairness." ${ }^{, 68}$ Even in a case highlighting the distinct purpose of juvenile court, the Supreme Court failed to recognize the potential of strengthening ethical oversight of judges.

As the Supreme Court expanded constitutional protections for participants in juvenile court, the ideology of the Court itself began to shift. By aligning the procedures of juvenile court more closely with adult criminal court, Supreme Court jurisprudence "criminalized" the juvenile justice system. ${ }^{69}$ As the American public became frustrated with perceived leniency for criminal actions by

64. Id.

65. McKeiver, 403 U.S. at 534. The Court's reference to "untrained" and "less than fully imbued" judges raises ethical issues of judicial competence.

66. A similar discrepancy exists today in immigration court. See generally Jaya Ramji-Nogales et. al., Refugee Roulette: Disparities in Asylum Adjudication, 60 Stan. L. Rev. 295 (2007); Michele Benedetto, Crisis on the Immigration Bench: An Ethical Perspective, 73 BROOK. L. REv. 467 (2008).

67. Although the creation of ethical guidelines is traditionally within the realm of the ABA and State Bar organizations, the Supreme Court does occasionally consider judicial ethics issues. See, e.g., Caperton v. A.T. Massey Coal Co., 129 S. Ct. 2252 (2009) (judge should have recused himself as a matter of due process when corporation that donated to his campaign appeared before him); Repub. Party of Minn. v. White, 536 U.S. 765 (2002) (Minn. Canon of Judicial Conduct, which prohibited candidates for judicial election from announcing their views or political issues, violated First Amendment); Bracy v. Gramley, 520 U.S. 899 (1997) (judge convicted of taking bribes from defendants in criminal cases is actual judicial bias); Liljeberg v. Health Servs. Acquisition Corp., 486 U.S. 847 (1988) (judge should have disqualified himself in proceeding in which his impartiality might reasonably be questioned); Stump v. Sparkman, 435 U.S. 349 (1978) (judicial misconduct did not render judge personally liable, despite the lack of formality).

68. McKeiver, 403 U.S. at 547-48.

69. See generally Edwards, supra note 6, at 7 ("Since the Gault case the criminalization of the juvenile courts has continued."); see also Alexes Harris, Diverting and Abdicating Judicial Discretion: Cultural, Political, and Procedural Dynamic in California Juvenile Justice, 41 LAw \& SoC'y REv. 387, 393 (2007) ("Thirty years after the 'constitutional domestication' of the juvenile court, a more punitive approach to crime and justice increasingly guides the juvenile system.") (internal citations omitted). 
youthful offenders, ${ }^{70}$ juvenile arrests for violent crime increased sixty-two percent from 1988 to $1994 .{ }^{71}$ With the public demanding "adult time for adult crimes, ${ }^{72}$ legislative changes sought to treat juveniles more like adult offenders. ${ }^{73}$ At the same time, state legislators amended the purpose clauses of state statutes defining juvenile court to include words such as "punishment" and "accountability," 74 and prosecutors played an increased role in court proceedings. ${ }^{75}$

\section{The Specialized Role of Juvenile Court}

Despite a decline in juvenile arrests for violent crime between 1994 and $2008,{ }^{76}$ the shift away from rehabilitation continued in juvenile court. Although inherent tensions between the rehabilitative and penal purposes of juvenile court have always existed, juvenile court is now viewed by some observers as employing a more punitive model, less focused on the "best interests" of a child. ${ }^{77}$ In light of this ideological transition, the distinction between juvenile court and adult criminal court has blurred. Indeed, numerous scholars have addressed the evolving nature of juvenile court, sparking debates over procedural reform, constitutional reform, and even the abolition of juvenile court entirely. ${ }^{78}$

However, while the differences between these courts are certainly narrower than Progressive reformers envisioned, juvenile delinquency court continues to

70. Randi-Lynn Smallheer, Sentence Blending and the Promise of Rehabilitation: Bringing the Juvenile Justice System Full Circle, 28 Hofstra L. Rev. 259, 271-72 (1999).

71. Nat'l Council of Juvenile and Family Court Judges, Juvenile Delinquency Guidelines: Improving Court Practice in Juvenile Delinquency Cases 13 (Spring 2005) [hereinafter Juvenile DELINQUENCY GuIDELINES].

72. Drizin \& Luloff, supra note 31 , at 265 .

73. Smallheer, supra note 70 , at 272. These reforms include relaxing restrictions regarding transfer of juveniles to adult courts, lowering the maximum age for jurisdiction in juvenile court, raising the maximum age for retaining a youth in a juvenile institution, using adult correctional facilities in sentencing, and imposing identical sentences on youth and adults convicted for the same offense. Id. (citing Hon. Lawrence L. Koontz, Jr., Reassessment Should Not Lead to Wholesale Rejection of the Juvenile Justice System, 31 U. RICH. L. REv. 179, 180 (1997)).

74. Juvenile Delinquency Guidelines, supra note 71, at 12.

75. For example, prosecutors can "defer prosecution if a child successfully completes a program of community service or counseling." Edwards, supra note 6, at 8. Prosecutors were "once unwanted and unnecessary in the juvenile court," but have since become "an integral part of its operation." Id. at 7.

76. U.S. Dep’t of Justice OfFice of Juvenile Justice and Delinquency Prevention, Statistical Briefing Bоок (2009), available at http://www.ojjdp.ncjrs.gov/ojstatbb/crime/JAR_Display.asp?ID=qa05201.

77. See, e.g., Drizin \& Luloff, supra note 31, at 265 (discussing a "wave of draconian new laws" that has "resulted in a more punitive justice system" for juveniles); Randi-Lynn Smallheer, supra note 70, at 273 ("The states' efforts to 'crack down' on juvenile crime thus reflect a shift toward more retributive sentencing policies."); see also Blitzman, supra note 24, at 77 (2007) (“To protect public safety, some juveniles are transferred [to criminal court] and are treated as adults.").

78. Feld, supra note 9, at 93. Contra Blitzman, supra note 24, at 94 (2007) ("Given the fact that it has been estimated that fifty percent of the juvenile court's subject matter involves care and protection and status offense cases, the compartmentalization that Feld recommends is problematic."). 
serve a specialized role in the criminal justice system. Central to this role is the fact that cases adjudicated in juvenile court always involve minors, a group deemed less culpable than their adult counterparts.

\section{A. JUVENILE OFFENDERS ARE "DIFFERENT": ROPER V. SIMMONS AND GRAHAM V. FLORIDA}

The Supreme Court acknowledged the unique situations of juvenile offenders in two recent cases, Roper v. Simmons and Graham v. Florida. In Roper, the Court considered whether execution of individuals under the age of eighteen at the time of the offense violated the Eighth and Fourteenth Amendments. ${ }^{79}$ At age seventeen, as a junior in high school, Christopher Simmons murdered a woman in Missouri. ${ }^{80} \mathrm{He}$ was tried as an adult, found guilty, and sentenced to death. ${ }^{81}$ The Supreme Court precedent applicable at the time was Stanford v. Kentucky, in which a divided court upheld the constitutionality of the death penalty for juvenile offenders over age fifteen but under age eighteen. ${ }^{82}$

The Court chose to reconsider this issue in the case of Christopher Simmons. The Court framed its discussion with an analysis of the three main differences between juveniles and adults. First, the Court considered scientific and sociological evidence demonstrating that "a lack of maturity and an underdeveloped sense of responsibility" are more often found in youth than in adults, resulting in "impetuous and ill-considered actions and decisions." 83 Second, juveniles are more vulnerable to negative influences, including peer pressure, and have less control over their personal environments. ${ }^{84}$ Third, the characters of juveniles are not as formed as adults but instead have more "transitory" personality traits. ${ }^{85}$ These factors suggested that juveniles "have a greater claim than adults to be forgiven for failing to escape negative influences in their whole environment." 86 As a result, the case for retribution is not as compelling. ${ }^{87}$

The "marked" differences between juveniles and adults caused the majority of states - and nearly every other country in the world - to reject the execution of juveniles. ${ }^{88}$ Recognizing this trend, the Supreme Court concluded that the Eighth and Fourteenth Amendments forbid imposition of the death penalty on individu-

\footnotetext{
79. Roper v. Simmons, 543 U.S. 551 (2005).

80. Id. at 556 .

81. Id. at 557-58.

82. Id. at 551 (citing Stanford v. Kentucky, 492 U.S. 361, 370-71 (1989)).

83. Id. (internal citations omitted).

84. Roper, 543 U.S. at 569.

85. Id. at 570 .

86. Id.

87. Id. at 571.

88. Id. at 572 .
} 
als for crimes committed under the age of eighteen. ${ }^{89}$ The Roper Court's analysis is notable not only for its reliance on scientific evidence to support its holding, but also because it arguably represents a jurisprudential shift away from a punitive approach to juvenile justice. ${ }^{90}$

This shift continued with the Court's reasoning in Graham v. Florida, in which the Court considered whether imposition of a life sentence without parole on a juvenile for a non-homicidal crime violates the cruel and unusual punishment prohibitions of the Constitution. ${ }^{91}$ Following the logic of Roper, the Court held that the Eighth Amendment forbids the sentence of life without parole for a juvenile offender who did not commit a homicide. ${ }^{92}$ The Court noted that developments in psychology and brain development since Roper "continue to show fundamental differences between juvenile and adult minds." ${ }^{93}$ Hence, imposing a sentence of life without parole would deny a juvenile the "chance to demonstrate growth and maturity." 94

For purposes of this discussion, the Court's ongoing acknowledgment that juvenile offenders deserve different treatment than adults reinforces the need for a unique court to handle juveniles. Even more significantly, the Court's analysis in both Roper and Graham emphasizes the importance of understanding the developmental and psychological issues relevant to juvenile delinquency. The sensitivity to these issues expressed by the Court is the type of sensitivity all juvenile court judges must possess to be effective. ${ }^{95}$

\section{B. THE STRUCTURE OF JUVENILE COURT}

Despite its increased "criminalization," juvenile court remains a court like no other. ${ }^{96}$ While most adult criminal courts are focused entirely on deterrence and punishment, juvenile court retains the goal of "identifying the underlying issues causing the delinquent behavior and providing interventions to address these issues." ${ }^{97}$ The rehabilitative component is therefore much more important in juvenile court. ${ }^{98}$ As a consequence, structural and procedural differences exist

89. Roper, 543 U.S. at 578. With this holding, the Supreme Court moved away from its analysis in Stanford toward a less harsh model of juvenile justice: "These considerations mean Stanford v. Kentucky should be deemed no longer controlling on this issue." Id. at 574. A similar Supreme Court shift had occurred three terms earlier in the context of the death penalty for the mentally retarded. See Atkins v. Virginia, 536 U.S. 304 (2002).

90. See generally Poncz, supra note 43.

91. Graham v. Florida, 130 S. Ct. 2011 (2010).

92. Id. at 2018 .

93. Id. at 2013 .

94. Id. at 2017

95. See infra discussion of judicial competence, Part V.B.

96. Edwards, supra note 6, at 7. For a discussion of adult problem-solving courts, see infra Part IV.B.

97. JuVENILE DELINQUENCY GUIDELINES, supra note 71, at 21 (2005).

98. One juvenile court judge explained that "my purpose is to rehabilitate" but "downtown in adult criminal court their purpose is to punish." Telephone Interview with Martina Peterson, Mo. Juvenile Court Comm'r (Jan. 21, 2010). 
between adult and juvenile court. ${ }^{99}$

In an attempt to reduce the stigma attached to juvenile court adjudications, the courts employ distinctive terminology. Charges are brought as "petitions" instead of "complaints" or "indictments," and "trials" are called "jurisdictional hearings." "100 Young offenders are referred to as "minors" or "delinquents," not "defendants" or "criminals," and convicted juvenile offenders receive "dispositions," rather than "sentences." division of superior court required by statute to have a presiding judge supervising administrative matters. ${ }^{102}$ Also, with some exceptions, the proceedings and records of juvenile court are not publicly available. ${ }^{103}$ Unlike criminal court convictions, juvenile court records in some cases can be sealed from public view when the minor turns eighteen. ${ }^{104}$

Some state statutes reinforce the juvenile court's duty to act in the best interests of the child, ${ }^{105}$ while others emphasize the court's responsibility to act in a parental role. But the best illustration of juvenile court as "different" can be found in the greater discretion of the juvenile court judge. As one judge commented, "I need to be more involved than I ever would in civil court. How do I make a decision [for a youth] that is personally, legally, and socially appropriate?"106

In addition, juvenile court judges have a wide variety of sentencing options. For example, juvenile offenders can be placed on informal or formal probation. ${ }^{107} \mathrm{~A}$ judge can also impose disposition alternatives such as counseling, mental health, or community service. ${ }^{108}$ For more serious offenses, judges may choose from an array of out-of-home placement options, including juvenile hall, county camps, residential treatment programs, or state juvenile justice authori-

99. Edwards, supra note 96, at 5 (Although each state's juvenile court is "unique in the way it is structured," there are "substantial similarities in the ways in which juvenile courts in all jurisdictions function.").

100. See id. at 6 .

101. See id.; see also In re Gault, 387 U.S. at 23-25 (A benefit of the juvenile court procedure is to classify the juvenile offender as a "delinquent" rather than as a "criminal," yet this term currently involves only slightly less stigma.); Poncz, supra note 43, at 285.

102. Center for Families, Children \& the Courts, Juvenile Delinquency Court Assessment 14 (2008), available at http://www.courtinfo.ca.gov/programs/cfcc/pdffiles/JDCA2008CombinedV1V2.pdf [hereinafter Juvenile Delinguency Court Assessment]; see also CAL. Welf. \& Inst. Code $\$ 246$ (West 2009).

103. CAL Welf. \& Ins. CODE $§ 676$ (a) (West 2009) ("Unless requested by the minor ... the public shall not be admitted to a juvenile court hearing."). The statute provides exceptions for hearings related to specific crimes, including murder, arson, and robbery, which are opened to the public.

104. See CAL Welf. \& Ins. Code $\$ 781$ (West 2009).

105. See id. at 6 n.20 (citing, by way of example, Ga. Code Ann. § 15-11-35 (West 2009); N.D. Cent. CodE § 27-20-31 (West 2009); VT. Stat. AnN. 33, § 5101 (West 2009)).

106. Interview with the Honorable Donna Hitchens, Supervising Judge, S.F. Unified Family Court, S.F., Cal. (Aug. 6, 2009).

107. Id.

108. See generally Juvenile Delinquency Guidelines, supra note 71, at 148-49 (discussing disposition sentencing options such as community service, referring youth to mental health agencies for treatment, or substance-abuse counseling and therapy). 
ties. ${ }^{109}$

To accomplish the goals of juvenile court, the judge's role "combines judicial, administrative, collaborative, and advocacy components." 110 The juvenile court itself is part of a wide-ranging structure with multiple participants, including not only lawyers, police, probation officers and court staff, but also parents, families, schools, and community organizations. ${ }^{111}$ Many delinquency cases can be informally resolved by one or more members of this broader system, leaving room for juvenile court judges to hear only the most serious cases. ${ }^{112}$ In the determination of a case, a judge must consider information available from legal proceedings, probation reports, social service agency reports, and from the parties (including family members) as well as attorneys. ${ }^{113}$

Notwithstanding these many players, it is often the juvenile court judge who is held accountable by the public for any "failings" in this system. ${ }^{114}$ In addition to his or her adjudicative duties, the juvenile court judge must therefore provide leadership to educate the community about the challenges and needs of juvenile court. $^{115}$

As part of this nontraditional role, judges must ensure resources and services are available for at-risk children and families. ${ }^{116}$ To do so, juvenile court judges have a "greater responsibility than other judges to know the resources available in the county in which they serve."117 Judges should also guarantee that cooperation exists among schools, probation officers, and other members of the system. ${ }^{118}$

109. Interview with the Honorable Donna Hitchens, supra note 106; see also E-mail from Martina Peterson, Mo. Juvenile Court Comm'r (Jan. 21, 2010) (on file with The Georgetown Journal of Legal Ethics) for a discussion of Missouri's "range of options" of placements for delinquent youth, including probation, county-operated residential treatment programs, private residential facilities, and state-operated community and residential treatment programs.

110. Edwards, supra note 96, at 25.

111. Id. at 8 .

112. Id. at 27.

113. See id. at 26.

114. Id. at 27.

115. See, e.g., CAL. R. CT., Standard 5.40(e) (2009), available at http://www.courtinfo.ca.gov/rules/ index.cfm?title $=$ standards\&linkid $=$ standard5_40. Standard 5.40(e)(7) provides that juvenile court judges should "[e]ducate the community and its institutions through every available means, including the media, concerning the role of the juvenile court in meeting the complex needs of at-risk children and their families." Id. See generally Edwards, supra note 6, at 29 (juvenile court judges should provide "to the community information about how well the juvenile court is completing the tasks assigned to it").

116. See, e.g., CAL. R. CT., Standard 5.40(e) (2009), available at http://www.courtinfo.ca.gov/rules/ index.cfm?title $=$ standards\&linkid $=$ standard5_40 ("Judges of the juvenile court $\ldots$ are encouraged to ... take an active part in the formation of a communitywide network to promote and unify private and public sector efforts to focus attention and resources for at-risk children and their families.").

117. Interview with the Honorable Donna Hitchens, supra note 106.

118. See, e.g., CAL. R. CT. 5.40(e)(4) (2009), available at http://www.courtinfo.ca.gov/rules/ index.cfm?title $=$ standards\&linkid $=$ standard5_40 ("Judges of the juvenile court $\ldots$ are encouraged to ... exercise a leadership role in the development and maintenance of permanent programs of interagency cooperation and coordination among the court and the various public agencies that serve at-risk children and their families."). Generally, the California Standard of Judicial Administration directs judges to do a great deal of work in 
These judicial activities promote community involvement and "advance the administration of justice" in juvenile courts. ${ }^{119}$

\section{THE PATH TO THE JUVENILE COURT BENCH}

In spite of their unique roles, juvenile court judges reach their positions on the bench in much the same way other judges do. Accordingly, procedures for appointment to the bench vary widely by jurisdiction. For example, in California, where state judges are either elected or appointed by a governor, the path to juvenile court starts with service on the superior court bench. ${ }^{120}$ As judges, these individuals work in a range of courts, including civil, criminal, and juvenile courts. ${ }^{121}$ Assignment to an individual court is within the discretion of the presiding judge of superior court. ${ }^{122}$ In Missouri, depending on the county, juvenile court judges are either appointed by the governor or elected. ${ }^{123}$ Each county in the state of Texas has a "juvenile board," which performs oversight functions for local juvenile justice systems and designates which judges will sit as juvenile court judges. ${ }^{124}$ In New York, juvenile court judges are publicly elected to the bench through a network of independent screening panels. ${ }^{125}$

Some juvenile court judges specifically request a permanent assignment to juvenile courtrooms. Others view an assignment in juvenile court as a necessary first step for higher judicial office. ${ }^{126}$ A 2008 study of juvenile courts in California found that most judges had long tenures working in juvenile

the community. Id. No other state has such a standard. E-mail from anonymous California retired juvenile court judge (Feb. 1, 2010) (on file with The Georgetown Journal of Legal Ethics). For additional examples of judicial activism beyond the traditional bench duties, see Edwards, supra note 96, at 30-31.

119. Hon. Arthur L. Burnett, Sr., What of the Future? Envisioning an Effective Juvenile Court, 15-SPG CRIM. JusT. 6, 13 (2000).

120. Interview with the Honorable Donna Hitchens, supra note 106.

121. See Harris, supra note 69, at 399.

122. Interview with the Honorable Donna Hitchens, supra note 106. Different jurisdictions use various terms to describe juvenile court adjudicators, including "magistrates," "hearing officers," "masters," and "associate judges." JuvEnILE DELINQUENCY GuidelinEs, supra note 71, at 31-32. In some jurisdictions, judicial "referees" or "commissioners" perform comparable duties to judges but are assigned to specific courtrooms. Harris, supra note 69 , at 399 .

123. Telephone Interview with Martina Peterson, supra note 98 . Missouri juvenile court benches are filled by judges and commissioners. Commissioners are selected by en banc panel of circuit court judges, and their selection must be approved by the governor. Mo. REv. STAT. $\$ 487.020(1)$, available at http://www.moga.mo.gov/ statutes/C400-499/4870000020.htm.

124. Texas Youth Comm'n, Overview of the Juvenile Justice System in TeXas (2009), http:// www.tyc.state.tx.us/about/overview.html.

125. N.Y. Unified Court System, Court Rules of the Chief Administrative Judge $§ 150.1$, available at http://www.nycourts.gov/rules/chiefadmin/150.shtml. The independent screening panels consist of persons selected by judges, including non-lawyers, as well as members of various bar associations. Id. In New York, juvenile delinquency cases are heard by Family Court judges. See Juvenile Delinquency, N.Y. Ciтy Faм. Cт., http://www.nycourts.gov/courts/nyc/family/faqs_juvenile.shtml (last visited Oct. 7, 2010).

126. See Harris, supra note 69, at 399-400. There are similar differences for lawyers in juvenile court. In some jurisdictions, such as San Francisco, it is deemed a privilege for experienced district attorneys and public 
delinquency. ${ }^{127}$ One-half of the judges reported serving in their current delinquency assignment for three years or more. ${ }^{128}$ Significantly, sixty-two percent of judicial officers had been attorneys practicing juvenile law before they came to the bench. ${ }^{129}$ Judicial officers reported that they had spent an average of twenty-two hours in "specialized training related to juvenile delinquency, dependency, and related subjects" the year before. ${ }^{130}$ Notably, the study did not report on any training related to judicial ethics. About half of the judicial officers indicated that they experience one or more "work-related barriers" to attending trainings, such as difficulty covering the time spent away from the bench and budget concerns. ${ }^{131}$

San Francisco juvenile court judges regularly attend in-house trainings, in addition to annual classes given by California's Center for Judicial Education and Research. ${ }^{132}$ New judges in San Francisco are required to attend the annual Juvenile Law Institute for Judges. Similarly, in Missouri, family court judges and commissioners must attend mandatory training every year, including Juvenile Justice Education trainings. ${ }^{133}$ However, many of these trainings do not focus on ethics. ${ }^{134}$

This level of expertise and experience has both positive and negative aspects for participants in the challenging environment of juvenile court. On one hand, juvenile court judicial officers appear to be some of the most experienced and trained bench officers in any specialized court. ${ }^{135}$ This suggests that juveniles appearing in delinquency court could have the benefit of a judge who understands both the law and the considerable array of sentencing options available to individual minors. Many judges who prefer to work in juvenile court do so with a sense of dedication to "working with young people."136

defenders to be assigned to juvenile court. Interview with Anonymous Public Defender, S.F., Cal. (June 30, 2009). As a result, the quality of lawyering in the San Francisco juvenile court is extremely high. Id.

127. Juvenile Delinguency Court Assessment, supra note 102, at 75 . This study was the judiciary's first "comprehensive research study of how the superior courts of California handle delinquency matters." Id. at 1. The study reported that the median length of judicial experience for judges, commissioners, and referees was 11.5 years. Id. at 74 . The term "judicial officers" used herein will refer to judges, referees, and commissioners.

128. Id. at 74 .

129. Id. at 75 .

130. Id. This amount of training is a sharp contrast to other judicial officers in the United States. For example, substantive training for immigration judges was cancelled in 2008 due to budget constraints. See Benedetto, supra note 66, at 486.

131. Juvenile DelinQuency Court Assessment, supra note 102, at 75.

132. Interview with the Honorable Donna Hitchens, supra note 106; see also CAL R. CT. 10.50 (2010).

133. Telephone interview with Martina Peterson, supra note 98. For more about Juvenile Justice Education in Missouri, see Juvenile Justice Education, Your Mo. CTs., http://www.courts.mo.gov/page.jsp?id=2284 (last visited Oct. 12, 2010).

134. Telephone interview with Anonymous Missouri Juvenile Court Commissioner (Jan. 21, 2010).

135. Contra Benedetto, supra note 66, at 486 ("[T]raining conferences for immigration judges were completely suspended for several years due to budgetary constraints.").

136. Harris, supra note 69, at 404-05. 
There are, however, downsides to experience. Judges could develop subtle biases from hearing multiple cases, since "[j]udges who sit for years in a criminal or juvenile court tend to hear the same stories over and over." ${ }^{137}$ Examples include gun possession cases in which a juvenile claims he or she simply "found" the gun, drug possession cases in which a juvenile claims the "police planted the drugs," or assault cases with a claim of self-defense. ${ }^{138}$ Judges who repeatedly hear these defenses "cannot help but be skeptical when yet another . . . juvenile respondent comes forward with the same story." 139

Judges also draw diverse lessons from their experience, not all of which serve the principles underlying juvenile court. For example, sociologist Alexes Harris' 2007 study of juvenile courts in Southern California found a "discordant bench" in which "the ways final case outcomes were decided varied" depending on whether judges had a "rehabilitative" or "literalist" (i.e., punitive) view of juvenile court. ${ }^{140}$ The study concluded that judges focusing on the rehabilitative aspect of juvenile court are likely to consider "individualized assessments of youth" and prioritize "treatment as an outcome." ${ }^{141}$ By contrast, judges with a literalist view of juvenile court tend to view delinquent minors as youthful offenders requiring "serious punishment" beyond the scope of juvenile court. ${ }^{142}$ These "competing notions of the substantive aims" of juvenile court raise concerns-similar to those raised by the Supreme Court in McKeiver-about inconsistencies in outcomes. ${ }^{143}$

Of course, inconsistent decision-making is possible in any court. In light of the historic tension between the juvenile court's dual purposes of rehabilitation and punishment, some judicial discrepancy should be expected. However, if juvenile court judges have starkly opposing views of the very purpose of the court itself (and by extension their roles on the bench), this could impair public confidence in the consistency and fairness of the process. ${ }^{144}$

This point is particularly critical because juvenile court presents practical challenges to those who operate in its courtrooms. Judges in delinquency court are "on the front-line, dealing with some of society's most difficult problems."145 As they decide individual cases, these judges must balance their statutory obligations with the needs of both juvenile offenders and victims. As they contemplate the best interests of a minor, judges must also consider community

137. Guggenheim \& Hertz, supra note 45, at 574.

138. Id.

139. Id. at 575 .

140. Harris, supra note 69, at 405-06.

141. Id. at 403 .

142. Id. at 402 .

143. Id. at 406 .

144. See generally id.

145. Juvenile Delinquency Guidelines, supra note 71, at 14 (Spring 2005). 
safety. $^{146}$

This balancing act has become even more important in recent years in some jurisdictions that allow juvenile dispositions to affect adult criminal court sentences. ${ }^{147}$ For example, the California Supreme Court recently determined that juvenile adjudications can be counted as "strikes" for purposes of the three strikes law when an offender reaches adulthood. ${ }^{148}$ Accordingly, proceedings in juvenile court can have significant consequences later in a youth's life.

\section{CHALLENGES FACING JUVENILE COURT JUDGES}

With increasing weight placed on juvenile court adjudications, it is even more essential for juvenile courts to have sufficient resources to balance the many considerations confronting a juvenile court judge. However, juvenile courts are notoriously "understaffed and overworked." ${ }^{149}$ In some jurisdictions, they lack resources and positions because the juvenile court is "perceived as less important." ${ }^{150}$ In the current economic climate, juvenile courts suffering from heavy budget cuts and staff furloughs may also lose innovative juvenile court programs. $^{151}$

Heavy judicial caseloads take a toll on both judges and court participants. For judges, an excessive docket makes it "difficult to spend the time you want on each case." 152 For youth offenders, parents, victims and other community members, a court process that is "hurried and disorganized [makes] them feel as

146. See id.

147. See, e.g., Ryle v. State, 842 N.E. 2d 320, 321-24 (Ind. 2005) (juvenile adjudications are reliable enough to be deemed "prior convictions" and can serve as the basis for enhancing an adult criminal sentence); State v. Hitt, 42 P.3d 732, 740 (Kan. 2002) (juvenile adjudications need not be charged in an indictment or proven to a jury beyond a reasonable doubt before they can be used in calculating a defendant's criminal history score under the Kansas Sentencing Guidelines Act); State v. McFee, 721 N.W.2d 607, 615 (Minn. 2006) ("[I]t is not inconsistent with the legislature's purpose in maintaining the juvenile justice system for sentencing courts to use prior juvenile adjudications in calculating criminal history under the Minnesota Sentencing Guidelines."); State v. Harris, 118 P.3d 236, 243-44, 246 (Or. 2005) (juvenile adjudications can increase sentences for adult felons so long as the existence of the prior juvenile adjudication is proved to a jury in the current case).

148. See People v. Nguyen, 209 P.3d 946, 949, 959 (Cal. 2009).

149. Edwards, supra note 96 , at 26.

150. Id. at 26; see also id. at 35 ("[J]uvenile court often occupies low status in the legal community ... [t]he low status is ... related to the fact that there is very little money to be made in juvenile court.").

151. Interview with the Honorable Donna Hitchens, supra note 106; see also, e.g., S.C. DEPT. OF JuvENILE Justice, RePORT ON PROGRESS 2009 (2009), available at http://www.state.sc.us/djj/pdfs/2009-chinn-report.pdf (addressing a twenty-three percent budget cut to the Department of Juvenile Justice in South Carolina, resulting in the elimination of approximately 200 full time staff positions, mandatory ten-day furloughs for all employees, and the elimination of all group homes and community based alternative placements); Press Release, Multnomah County Oregon Department of Community Justice, Multnomah County's Juvenile Justice Innovations Threatened by Budget Cuts 2 (Jan. 9, 2004), available at http://www.co.multnomah.or.us/dcj/ Detention_reform_Detention_reform_press_conference0104.pdf (stating that the Department of Community Justice has lost up to seventy percent in state funding, despite innovative and effective programs).

152. Interview with the Honorable Donna Hitchens, supra note 106. 
if their case is just being mechanically processed." ${ }^{153}$ This is particularly significant because of the different "mission" of juvenile court-judges are expected to consider more than simply the facts of an offense to determine the best placement for a child. ${ }^{154}$

Another compromising influence may be personal ambition. The Harris study found that an "important aim" among judges was to retain their current positions ${ }^{155}$ or achieve promotions that would "lead them beyond the juvenile court." ${ }^{156}$ They "sought to create reputations that would generate prestige and connections to elected [office]." 157 Participants in the study were concerned about public perception of their judging abilities, including the expectations of police, the media, and government agencies. ${ }^{158}$ Such considerations may force excessive attention to how cases will play in the public eye. Judges "who are afraid [for their reputations] are heavy sentencers." ${ }^{159}$ Consequently, a judge's own career aspirations can have a significant influence on his or her determinations in juvenile court. Nevertheless, the current judicial ethics scheme does not recognize these challenges of juvenile court.

\section{The ABA Code of Judicial Conduct And Juvenile Court Judges}

The American Bar Association Code of Judicial Conduct is designed to be a model code, and as such it has no binding legal effect unless jurisdictions adopt elements of the Code by statute or court rule. ${ }^{160}$ Although the Code itself does not have the "force of law or regulation," it reflects a "judicial consensus regarding appropriate behavior" and is influential in "giving content to the constitutional standards under which disciplinary proceedings are charged."161

Nearly all states have substantively adopted the ABA Code of Judicial Conduct in its entirety as the ethical code for juvenile court judges. ${ }^{162}$ The $A B A$ Code thus provides uniformity between jurisdictions and forms "the foundation for a

153. Juvenile DelinQuency Court Assessment, supra note 102, at 63.

154. Interview with the Honorable Donna Hitchens, supra note 106.

155. Harris, supra note 69, at 399.

156. Id. at 404 .

157. See id. at 399.

158. See id. at 400 .

159. Interview with the Honorable Donna Hitchens, supra note 106.

160. See James J. Alfini ET. AL., Judicial Conduct And Ethics $§ 1.03$, 1-6 (4th ed. 2007).

161. Kloepfer v. Comm'n on Judicial Performance, 49 Cal. 3d. 826, 838 n.6 (1989) (affirming an expectation that judges will comply with the Code).

162. See Cal. Code of Jud. Ethics (West 2010); Co. Code of Jud. Conduct (West 2009); Fla. Stat. Ann., Code of Jud. Conduct (West 2010); Ill. Comp. Stat., Code of Jud. Conduct (West 2010); Md. Rules of Ct., Rule 16-813 (2008); Mass. Gen. Laws ch. 3, § 3:09 (West 2009); Mich. Comp. Laws Ann., Code of Jud. Conduct (West 2009); N.J. Rules of CT., App. to part 1 (West 2009); N.Y. Jud. Law, Book 29 App. (McKinney 2008); N.C. Gen. Stat., Code of Jud. Conduct (West 2009); Ohio Rev. Code Ann., Code of Jud. Conduct (West 2009); Tex. Gov't Code AnN., tit. 2, subtit. G, app. B (West 2009); VA. Code Ann., CAnons of Jud. Conduct (West 2009). 
national body of law concerning judicial conduct."163

The current ABA Code of Judicial Conduct Preamble starts with the premise that "an independent, fair, and impartial judiciary is indispensable to our system of justice." ${ }^{164}$ All judges are required to make competent decisions, free from bias or prejudice. ${ }^{165}$ Judges are obligated to promote the independence, integrity, and impartiality of the judiciary, and avoid both impropriety and the appearance of impropriety. ${ }^{166}$

\section{A. THE ABA CODE OF JUDICIAL CONDUCT: HISTORICAL BACKGROUND}

The ABA Code of Judicial Conduct was an outgrowth of canons created for a more traditional type of judging than is appropriate for a juvenile court judge. Like most American legal standards, the Code drew on experience under English common law. Although societies generally have sought "to assure the impartiality of the judges who held sway over them," English kings believed it was their royal right to remove any judge who refused to consult with them in the process of deciding cases. ${ }^{167}$ Such royal prerogatives were incompatible with the ideal of an independent judge who could protect citizens against royal abuse. ${ }^{168}$

Following the revolution, the American founders responded to perceived inadequacies of the pre-Revolution judiciary. Specifically, the framers sought to minimize the potential for undue influence on judges in the United States. This condition required life tenure for federal judges, who could be removed from the bench only through the impeachment process. ${ }^{169}$

In the first few decades of the twentieth century, the judiciary came under attack by progressive reformers and legal realists. ${ }^{170}$ Judges were condemned as corrupt members of the privileged class who stood in the way of reform

163. AlFinI ET AL., supra note $160, \S 1.03,1-7$.

164. ABA Model CODE OF JUdiCIAL CONDUCT pmbl. (2007), available at http://www.abanet.org/judicialethics/ ABA_MCJC_approved.pdf.

165. Alfini ET AL., supra note $160, \S 3.01,3-2$.

166. ABA Model Code of Judicial Conduct Canon 1 (2007), available at http://www.abanet.org/ judicialethics/ABA_MCJC_approved.pdf.

167. Randall T. Shepard, Campaign Speech: Restraint and Liberty in Judicial Ethics, 9 GEO. J. LEGAL ETHICS 1059, 1060 (1996).

168. See id. at 1061-62 (This conflict led to "such epic events as the removal of Chief Justice Coke for his refusal to promise that he would consult with King James.").

169. See id. at 1062. Impeachment is a time-consuming process with extreme results, and procedures became necessary to deal with lesser judicial misconduct. Congress eventually developed a method for lesser punishment of federal judges who do not deserve removal from the bench. See id. at 1063; see also Judicial Councils Reform and Judicial Conduct and Disability Act of 1980, Pub. L. No. 96-458, 94 Stat. 2035, 2038-9 (1980) (codified at 28 U.S.C. $\$ \S 331,332,372$ (1981)); ALFINI ET AL., supra note 160, § 1.04, 1-9 (Impeachment procedures "provide[] for only one sanction — the draconian penalty of removal—which was not appropriate for all or even most cases of judicial misbehavior.").

170. See generally Bruce A. Green \& Rebecca Roiphe, Tradeoffs of Candor: Does Judicial Transparency Erode Legitimacy?, 64 N.Y.U. AnN. Surv. Am. L. 497, 514-16 (2009). 
legislation. ${ }^{171}$ As public outcry against judges increased, the American Bar Association attempted to respond to this "perceived crisis in confidence in the judiciary." ${ }^{172}$ In 1924, the ABA adopted the model Canons of Judicial Ethics. ${ }^{173}$ The Canons were drafted by the ABA's Committee on Judicial Ethics, led by Chief Justice William Howard Taft. The Committee created thirty-four Canons designed to be "an ideal guide of behavior, rather than an enforceable set of rules." 174

These early Canons focused on judicial demeanor. For instance, the Preamble to the Canons declared that "[j] udges ought to be more learned than witty; more reverent than plausible; and more advised than confident." ${ }^{175}$ Rules regulating judicial behavior were designed to assuage public concerns about judicial discretion; in essence, judges were advised to apply the law "scientifically" instead of deciding cases based on their own partialities. ${ }^{176}$

\section{B. THE CURRENT ABA CODE OF JUDICIAL CONDUCT: INSUFFICIENT FOR JUVENILE COURT}

The ABA amended the judicial ethics codes in 1972, 1990, and 2007. Each revision produced debates about the appropriate content of the Code ${ }^{177}$ For example, the goal of the 1972 revision was "to create bureaucratic divisions between the judiciary and the political branches of government, preventing bias in proceedings, and promoting the efficient administration of justice." 178 The Code accordingly governed extra-judicial activities, including compensation for those activities as well as financial dealings and personal interest disqualifications. $^{179}$

The current version of the $A B A$ Code specifies that the Code is intended to apply to "anyone who is authorized to perform judicial functions, including an officer such as a justice of the peace, magistrate, court commissioner, special master, referee, or member of the administrative law judiciary." ${ }^{80}$ The Code's provisions "are premised upon the supposition that a uniform system of ethical principles should apply to all those authorized to perform judicial functions."181

171. See id. at 517.

172. Id. at 514

173. Id. at 518; see also Vincent R. Johnson, The Ethical Foundations of American Judicial Independence, 29 Fordham URb. L.J. 1007, 1013 n.33 (2002).

174. AlfinI ET AL., supra note $160, \S 1.03,1-5$; see also Green \& Roiphe, supra note 170 , at 518.

175. Green \& Roiphe, supra note 170, at 519 n.125 ("Judges ought to remember that their office is jus dicere not jus dare; to interpret the law, and not to make the law, or to give law.") (citing ABA Report of Committee on Judicial Ethics (1923) (quoting Francis Bacon, Essay on Judicature)).

176. Id. at 519 .

177. For a detailed explanation of the development of judicial ethics codes, see generally $i d$.

178. Id. at 534 .

179. Id.

180. ABA Model Code of Judicial Conduct, § I.B (2007).

181. ABA Model Code of Judicial Conduct, $\S$ I, cmt. 1 (2007). 
While the Code does not reference the fact that the role of a juvenile court judge is distinctly different from others who perform judicial functions, it does recognize that judges in certain courts have distinct adjudicative responsibilities from their more mainstream counterparts.

Specifically, the issue of alternative courts arose during the 2007 revisions as "problem-solving" courts (such as drug courts, mental health courts, and domestic violence courts) had become more common. ${ }^{182}$ Much like juvenile court, the focus of problem-solving courts is not simply the adjudication of individual cases; they are also intended to assist communities in solving social problems. ${ }^{183}$ Unlike juvenile courts, however, alternative courts usually do not wrestle with a historical tension between the goals of rehabilitation and punishment.

Problem-solving courts involve different roles for a judge, who must serve as "the leader of a team rather than a dispassionate arbitrator." 184 To bring a case to resolution, judges in problem-solving courts hear information from a variety of sources. The "defendant" is not always present for discussions, and judges are encouraged to actively and directly seek information from individuals. ${ }^{185}$ As a result, judges in problem-solving courts risk violating rules prohibiting ex parte communications and other ethical rules. ${ }^{186}$ Like judges in juvenile court, judges in these alternative courts are left with no specific ethical guidance for the unique challenges of their courts.

As the ABA undertook the process that would ultimately result in the 2007 revised Model Code of Judicial Conduct, the Commission responsible for the revision held thirteen public hearings. In the course of those hearings, commentators informed the Commission of the developing need for judicial guidance in problem-solving courts. ${ }^{187}$

With no ethical guidelines existing for these particular circumstances, judges in innovative courts hoped that "the new Code would address [the] issues and the concerns that arise out of this new way of conducting court proceedings." 188

Unfortunately, the ABA fell short of adopting guidelines specifically for alternative courts. ${ }^{189}$ The revised guidelines acknowledge that judges in these

182. See Louraine C. Arkfeld, Ethics for the Problem-Solving Court Judge: The New ABA Model Code, 28 Just. Sys. J. 317 (2007). Specifically, the Code acknowledges the advent of these alternative courts, stating "[i]n recent years many jurisdictions have created what are often called 'problem solving' courts, in which judges are authorized by court rules to act in nontraditional ways." ABA Model CODE OF JUDICIAL CONDUCT, § I cmt. 3 (2007).

183. See Arkfeld, supra note 182, at 317.

184. Id.

185. See id.

186. See id.

187. Id. at 318 .

188. Id.

189. See Mark I. Harrison, The 2007 ABA Model Code of Judicial Conduct: Blueprint for a Generation of Judges, 28 Just. Sys. J. 257, 264 (2007) (Though witnesses urged the Commission to create unique ethical rules 
types of courts work "outside the context of their usual judicial role as independent decision makers on issues of fact and law." ${ }^{, 190}$ But the Commission left the problem of ethical guidance for these courts to the drafters of local rules: "When local rules specifically authorize conduct not otherwise permitted under these Rules, they take precedence over the provisions set forth in the Code." 191

By leaving these issues to be resolved at the state and local level, the ABA's reluctance to create ethical guidelines for the unique circumstances of nontraditional courts creates a dilemma for judges in these courts. The same problem exists for juvenile court judges, who share characteristics of judges in both traditional and problem-solving courts.

Without a single applicable code of ethics, state legislatures, individual jurisdictions, and advocacy groups have filled in the gap with statutes, rules, and training materials specifically designed for juvenile court judges. Thus, a juvenile court judge faced with an ethical dilemma must consult multiple sources of overlapping guidelines. ${ }^{192}$ In addition to the ABA Code of Judicial Conduct as adopted by individual states, juvenile court judges are subject to state and local rules of court, ${ }^{193}$ court administrative rules, and the Rules of Professional Conduct for attorneys. Juvenile court judges are offered more guidance from advocacy groups, such as the National Council of Juvenile and Family Court Judges. ${ }^{194}$

Ironically, the ABA itself is involved with trainings for juvenile court judges as part of the National Child Welfare Resource Center, which "provides free training and technical assistance to agencies, courts, and attorneys on all legal and judicial aspects of the child welfare system." ${ }^{195}$ Furthermore, the ABA Center on Children and the Law is developing a comprehensive set of "Judicial Excellence Standards." These standards will address court organization, judicial

for these courts, the Commission was "ultimately unwilling to do so because therapeutic courts are too numerous and varied to enable the Commission to devise enforceable rules of general applicability for such courts.").

190. ABA Model Code of Judicial Conduct, § I cmt. 3 (2007). For instance, "judges presiding in drug courts monitoring the progress of participants in those courts' programs may be authorized and even encouraged to communicate directly with social workers, probation officers, and others." ABA MODEL CODE OF JUDICIAL Conduct, § I cmt. 3 (2007).

191. ABA Model Code of Judicial Conduct, § I cmt. 3 (2007).

192. See Juvenile Delinquency Guidelines, supra note 71, at 23 (National Council of Juvenile and Family Court Judges advocates judicial collaboration but recognizes the potential conflict with ethical rules regarding ex parte communication).

193. See, e.g., CAL. Rules of Court, Standard 5.40 (2009), available at http://www.courtinfo.ca.gov/rules/ index.cfm?title=standards\&linkid=standard5_40 (encouraging juvenile court judges to follow eleven "rules" in addition to their adjudicatory duties).

194. See, e.g., Juvenile Delinquency Guidelines, supra note 71; National Juvenile Defender Center, MacArthur Juvenile Court Training Curriculum (2000), available at http://www.njdc.info/macarthur2.php. 195. About Us, NAT'L Child Welfare Resource CenTER, http://www.abanet.org/child/rclji/aboutus.html (last visited Oct. 6, 2010). 
selection and assignment, judicial administration, and judicial education. ${ }^{196}$ The standards note that "[e]thics training is critical to help new judges understand the responsibilities that come with hearing [juvenile court] cases and ensure that they can comfortably embrace those responsibilities." ${ }^{197}$ However, these standards will have no influence on the ABA Code of Judicial Conduct. Thus, although one arm of the ABA recognizes the importance of specific ethical guidance and training for juvenile court judges, its own Code of Judicial Conduct does not.

Although these sorts of training materials are certainly useful, they provide neither uniform standards nor common grounds for discipline of judges who fail to follow such guidelines. Moreover, these many sources of guidance are themselves indicative of a problem. Juvenile court judges are often overworked in a system with minimal resources. ${ }^{198}$ These judges often do not have the time to consider multiple sources of authority on a regular basis. As one Missouri judge explained, "There are statutes that apply [to us], rules of evidence, civil procedure, criminal procedure that apply .... We've got rules all over the place." ${ }^{199}$ Another judge commented, "[It] would be easier to have one set of rules." ${ }^{200}$ A diligent judge could consult multiple sources and still be unclear about her ethical duties.

\section{Recommendations: The NeEd For a Revised ABA Code of Judicial CONDUCT For Juvenile COURT}

Although the Supreme Court, state legislatures, court participants, and the public view juvenile court as "different," the ABA Code of Judicial Conduct does not. The fact that current codes of judicial conduct were not designed for-and are not sufficient for-the special needs of juvenile court raises significant concerns. Experts agree that the juvenile justice system requires additional guidelines to improve the court's practices. ${ }^{201}$ Judges themselves appreciate that "there are times when our responsibilities perhaps require a little bit of deviation from a strict code." ${ }^{202}$ However, despite the fact that juvenile court judges face different challenges than their counterparts in other courts, the country's premier source of judicial ethics guidelines does not recognize these differences.

Accordingly, the ABA Code of Judicial Conduct should be amended to include provisions specifically for juvenile court judges. A simple, low-cost and practical

196. aba Center on Children and the Law, Judicial Excellence in Child Abuse and Neglect Proceedings: Principles and Standards for Court Organization, Judicial Selection and Assignment, Judicial Administration, ANd Judicial EduCATion (Sept. 2009) (manuscript on file with author).

197. Id at Standard D.1.

198. See supra note 151.

199. Telephone Interview with Martina Peterson, supra note 98.

200. Telephone Interview with Anonymous Missouri Juvenile Court Commissioner (Jan. 21, 2010).

201. See Juvenile DelinQuency Guidelines, supra note 71, at 15 . As one judge succinctly stated, "I think there should be greater clarity." Interview with the Honorable Donna Hitchens, supra note 106.

202. Id. 
revision would provide juvenile court judges with uniform guidelines suited to their unique roles. To initiate this process, this article proposes amendments related to three specific ethical issues facing juvenile court judges: ex parte communications, competence, and decorum.

Critics may respond to these suggestions by arguing that the ABA's Code was drafted in an intentionally broad manner, allowing local jurisdictions to create rules for specialized courts if they so choose. Unfortunately, this approach assumes an activist local court that may not be present in all locations. Even in jurisdictions that implement such rules, juvenile court judges are left to struggle with a myriad of guidelines. As such, adjudications may vary widely from state to state. A uniform model code tailored to the needs of juvenile court is therefore necessary.

Some juvenile court judges may argue that they would prefer that ethical rules treat them like any other judge in the context of ethics. However, this argument fails to address the different roles and responsibilities of juvenile court judges. Others may contend that simply revising a model Code of Judicial Conduct cannot guarantee any substantive changes in the daily lives of judges and litigants. It is certainly true that additional measures would likely need to be taken after implementation of these code revisions, possibly including revised disciplinary procedures to increase accountability of juvenile court judges. The proposals below should be viewed as a first step, encouraging ethical authorities to recognize the distinctions inherent in juvenile court and thereby simplify the role of judges.

\section{A. EX PARTE COMMUNICATIONS}

One area requiring revision for juvenile court judges is ex parte communications. The current ABA Model Code of Judicial Conduct, like every set of Model Codes before it, prohibits ex parte communications. ${ }^{203}$ These communications can be defined as those that "involve fewer than all of the parties who are legally entitled to be present during the discussion of any matter."204

The purpose of the ex parte prohibition is to ensure that no party gains an advantage by presenting information to a judicial decision maker without notice to all other parties. ${ }^{205}$ In this way, every person who has an interest in a legal proceeding may be afforded the right to be heard. ${ }^{206}$ In addition, allowing ex parte communications - even if a judge correctly decides a case with no undue

203. ABA Model Code of Judicial Conduct R. 2.9(A) (2007), available at http://www.abanet.org/ judicialethics/ABA_MCJC_approved.pdf. The Code provides that "a judge shall not initiate, permit, or consider ex parte communications.” ABA Model Code of Judicial Conduct R. 2.9(A) (2007).

204. AlFinI ET. AL., supra note 160, § 5.02, 5-2.

205. See Leslie W. Abramson, The Judicial Ethics of Ex Parte and Other Communications, 37 Hous. L. Rev. 1343,1355 (2000).

206. See id. 
influence - could undermine public confidence in an impartial judiciary. ${ }^{207}$

At the same time, ex parte communications are sometimes necessary. ${ }^{208}$ Accordingly, the Code establishes exceptions to the ex parte ban in particular circumstances. For example, a judge may communicate ex parte for "scheduling, administrative, or emergency purposes," provided the judge "reasonably believes" no party will gain an advantage in the case and the judge promptly notifies all parties of the communication. ${ }^{209}$ Exceptions also exist for soliciting written advice from a "disinterested expert," consulting with court staff, and conferences related to settling a case. ${ }^{210}$

Furthermore, the Code allows a judge to "initiate, permit, or consider" ex parte communications "when expressly authorized by law to do so." ${ }^{211}$ In the comment following the rule, the Code explains that these circumstances include service "on therapeutic or problem-solving courts, mental health courts, or drug courts" in which judges "assume a more interactive role" with parties, probation officers, social workers, and others. ${ }^{212}$

This exception is particularly interesting, since the Code defines the term "law" as encompassing "court rules as well as statutes, constitutional provisions, and decisional law. ${ }^{213}$ In this way, the ABA allowed various other authoritiescourt administrators, state legislatures, judges creating precedential case $1 \mathrm{law}^{214}$ - to carve out exceptions to the ex parte prohibition should they choose to do so. ${ }^{215}$

This broad provision has created significant inconsistencies among jurisdictions. For example, judges in one drug court created a "waiver" process requiring defendants to consent to judges' considerations of ex parte communications in

207. See id. at 1356 .

208. See generally JuVEnILE DelinQuency Guidelines, supra note 71, at 23 (discussing how juvenile court judges must balance community and system collaboration with ex parte restrictions).

209. ABA Model Code of Judicial Conduct R. 2.9(A)(1)(a)-(b) (2007), available at http://www.abanet.org/ judicialethics/ABA_MCJC_approved.pdf.

210. ABA Model Code of Judicial Conduct R. 2.9(A)(2)-(4) (2007), available at http://www.abanet.org/ judicialethics/ABA_MCJC_approved.pdf.

211. ABA Model Code of Judicial Conduct R. 2.9(A)(5) (2007), available at http://www.abanet.org/ judicialethics/ABA_MCJC_approved.pdf.

212. ABA Model Code of Judicial Conduct R. 2.9 cmt. 4 (2007), available at http://www.abanet.org/ judicialethics/ABA_MCJC_approved.pdf. While drafting this Comment, the ABA Commission considered testimony about the ways in which alternative court adjudications can be "in tension with the requirement that judges be and appear impartial and with traditional rules governing ex parte communications." Mark I. Harrison, The 2007 ABA Model Code of Judicial Conduct: Blueprint for a Generation of Judges, 28 Just. SYs. J. 257, 264 (2007).

213. ABA Model Code of Judicial Conduct, terminology (2007), available at http://www.abanet.org/ judicialethics/ABA_MCJC_approved.pdf.

214. See, e.g., In re W.T.L., 656 A.2d 1123 (D.C. Ct. App. 1995).

215. See Abramson, supra note 205, at 1384 ("The scope of an 'authorized by law' exception includes constitutional, statutory, and state and local rule provisions, as well as court orders or judicial decisions expressly permitting communications in the absence of any or all counsel."). 
exchange for admission to the drug court. ${ }^{216}$ In this instance, judges are deciding for themselves whether they are allowed to communicate in an ex parte manner. California already provides a limited exception to the ex parte prohibition for child custody proceedings, allowing such communication between court child custody mediators and attorneys or the court. ${ }^{217}$

In 2008, the Idaho Supreme Court added a provision to amend the state's judicial ethics codes to permit a judge presiding in a criminal or juvenile problem-solving court to engage in ex parte communications with "members of the problem-solving court team at staffings" and through written documentation. $^{218}$ Notably, a judge involved with ex parte communications regarding a defendant or juvenile in such a case cannot later preside over "termination proceedings, probation violation proceedings or sentencing in that case," ostensibly to limit any potential for bias and preserve due process safeguards. ${ }^{219}$ In this way, the Idaho approach recognizes that ex parte conversations can sometimes be useful, but should not be a determining factor in the resolution of a case.

Although elements of juvenile court arguably fall into the "problem-solving court" category, whether ex parte communications should be allowed in juvenile court is subject to dispute. ${ }^{220}$ The unique nature of juvenile court suggests that judges in this court should not be subject to the same ex parte ban as all other judges. After all, ex parte communications forbidden in most courts could enable a juvenile court judge to obtain necessary information about a child or family history, particularly since juvenile court judges are encouraged to comprehensively engage with extra-judicial individuals such as caseworkers, school counselors, and law enforcement officials. ${ }^{221}$

216. J. Vincent Aprile II, The Error of Legitimizing Ex Parte Communications, 18-SPG CRIM. JuST. 60, 61 (2003).

217. Cal. R. Ct. 5.235(d) (2009); see also CAL. Family Code § 216. Not all ex parte communications will negatively impact a court proceeding. See, e.g., In re W.T.L., 656 A.2d 1123 (D.C. Ct. App. 1995) (juvenile court judge's ex parte communication regarding a juvenile delinquent appearing before the judge was deemed harmless error).

218. Idaho Code of Judicial Conduct Canon 3(B)(7)(f) (2008), available at http://www.judicialcouncil. idaho.gov/code.pdf; see also Am. Univ. Justice Programs Office, Sch. of Pub. Affairs, Frequently Asked Questions Series: Drug Court Policies Regarding the Conduct and Confidentiality of Staffings (Oct. 23, 2009), available at http://www1.spa.american.edu/justice/documents/2648.pdf; Michael Henderson, Ex Parte Communications-Adapting an Adversarial Rule to the Problem-Solving Setting, The Advocate (Idaho), Vol. 51, 48-9 (Sept. 2008). "Staffing" is defined as "a regularly scheduled, informal conference not occurring in open court, the purpose of which is to permit the presiding judge and others, including counsel, to discuss a participant's progress in the problem solving court, treatment recommendations, or responses to participant compliance issues.” IdAHo Code of Judicial Conduct Canon 3(B)(7) Explanation, available at http://www.isc.idaho.gov/ links/Order\%20Explanation.pdf.

219. Henderson, supra note 218 , at $48-9$.

220. See discussion supra Part III.A regarding juvenile courts as "different" and possessing unique purposes.

221. See CAL. R. CT., Standard 5.40 (2009) (encouraging juvenile court judges to confer with public law office leaders and various public agencies that serve at-risk children, and maintain close liaison with school authorities). 
Additionally, as discussed in Part III.B, supra, juvenile delinquency court judges play a different role than judges in adult court. Juvenile court judges are responsible not only for deciding individual cases, but are also expected to be involved with community and juvenile justice system collaboration. ${ }^{222}$ Concern about violating ex parte rules could discourage judges from collaborative efforts that would be consistent with the purpose of juvenile court. One judge noted, "If I'm not allowed to ask questions, if I can't be involved, how can I do justice" in juvenile court? $?^{223}$

Conversely, allowing juvenile court judges to communicate ex parte presents a risk that a youth could suffer from an unfair or biased hearing. ${ }^{224}$ The Supreme Court held in Gault that juvenile court participants are entitled to fundamental fairness in their court proceedings. ${ }^{225}$ If a judge is permitted to have ex parte conversations with caseworkers or government attorneys regarding elements of a youth's delinquency case, the youth could be at a disadvantage; this situation would raise obvious due process concerns.

Moreover, whenever one counsel has access to the judge and opposing counsel does not, the "appearance of impropriety is immediately present."226 This factor is particularly important in juvenile delinquency proceedings. Given the extreme judicial discretion discussed in Part V.C, infra, juvenile court judges should arguably be held to the strictest ethical guidelines possible.

The ABA evaded the opportunity to clarify the application of the ex parte prohibition to juvenile court judges. Instead, the vague standard "expressly authorized by law" enables judges to engage in ex parte communications in a variety of circumstances. Theoretically, the ABA would permit juvenile court judges (like judges in drug court) ${ }^{227}$ to engage in ex parte discussions if they choose to do so; all that would be required is a declaration to that effect by a presiding judge of a juvenile court. ${ }^{28}$ While there may be some benefits to allowing individual jurisdictions to create their own rules, this approach could eventually lead to inconsistent regulations regarding one of the most important concepts in judicial ethics. The ABA's credibility is also at risk if its nearly

222. See discussion, supra Part III.B. A 2008 study by California's Administrative Office of the Courts found that eighty-five percent of judicial officers in juvenile court meet with other "justice partners" regularly, and one third of bench officers interviewed believe that courts should meet with them more often; see also JUVENILE DELINQUENCY GuIDELINES, supra note 71, at 25.

223. Interview with the Honorable Donna Hitchens, supra note 106 (Judges are "constantly on a tightrope: What can we say, what can't we say?").

224. Cf. Aprile, supra note 216, at 62 (discussing ex parte communications in the context of drug court proceedings).

225. Guggenheim \& Hertz, supra note 45 , at 558 .

226. Compare Aprile, supra note 216, at 60, with ABA Model Code of Judicial Conduct Canon 1 available at http://www.abanet.org/judicialethics/ABA_MCJC_approved.pdf (requiring that judges avoid both impropriety and the appearance of impropriety).

227. See Aprile, supra note 216, at 62.

228. Of course, such a declaration may run afoul of particular state or local judicial conduct rules. 
century-long ban on ex parte communications can be so casually disregarded in some courts.

To prevent this, the ABA Code of Judicial Conduct should acknowledge the complicated situations of juvenile court judges regarding ex parte communications. As discussed above, the Idaho rule recognizes different judicial roles in juvenile court: Ex parte conversations are allowed when the judge is acting in a problem-solving manner, but that judge is then forbidden from presiding in the ultimate sentencing disposition in that case. This approach protects the individual minor from any disadvantage as a result of the ex parte communications, but also preserves the juvenile court judge's ability to collaborate with other service providers.

The ABA should amend the current Model Code to provide more guidance to juvenile court (and other problem-solving court) judges. The amended provision should provide:

Rule 2.9(A): "A judge may not initiate, permit, or consider ex parte communications, or consider other communications made to the judge outside the presence of the parties or their lawyers, concerning a pending or impending matter, except as follows:

(6) When a juvenile court judge is serving in a problem-solving capacity. This capacity includes presiding over a juvenile diversion court or working with a court team to resolve a case through alternative sentencing. If a case is not resolved at the problem-solving stage, a judge who has received ex parte communications shall not preside over dispositions or probation proceedings in that case.",229

\section{B. COMPETENCE}

Like the prohibition against ex parte communications, judicial competence has been an essential element of every code of judicial conduct. ${ }^{230}$ The 2007 Model Code requires every judge to be competent, meaning judges must perform judicial and administrative duties with "the legal knowledge, skill, thoroughness, and preparation reasonably necessary." ${ }^{231}$ For instance, the Missouri Supreme Court established its test for judicial incompetence as "whether the conduct at issue establishes that the [judge] lacks the requisite ability, knowledge, judgment, or diligence to consistently and capably discharge the duties of the office he or

229. Proposed amendments are italicized.

230. See Alfini Et AL., supra note 160, § 1.03, 1-9 (citing ABA Model Code Canon 3A(1) (1972)); ABA Model Code Canon 3(A)(2)(1990); ABA Model Code of Judicial Conduct R. 2.5 (2007), available at http://www.abanet.org/judicialethics/ABA_MCJC_approved.pdf.

231. ABA Model Code of Judicial Conduct R. 2.5 cmt. 1 (2007), available at http://www.abanet.org/ judicialethics/ABA_MCJC_approved.pdf. 
she holds."232

Although every judge has a duty to fulfill his or her obligations with competence, the term has a broader meaning for judges in courts dealing with specialized populations. For example, as discussed above, juvenile court judges are required to be community educators in addition to serving the role of adjudicators. Despite the clear need for additional definitions of "competence," the ABA Code of Judicial Conduct does not specifically address any of the additional competency factors required of juvenile court judges.

For that reason, state and local court rules and training manuals require juvenile court judges to be educated in a wide variety of areas. ${ }^{233}$ In addition to a thorough understanding of juvenile law, delinquency judges must be trained in theories of human development and family and group dynamics, as well as have knowledge of available community or government resources. ${ }^{234}$ Furthermore, concepts relating to psychological development of youth, such as those utilized by the Supreme Court in Roper, have become necessary elements of a juvenile court judge's competence: Judges should "fully understand and appreciate the stages of child development, the educational needs of children at various stages in their development, and child behavioral issues." 235

A juvenile court judge may be trained in these factors by local authorities or advocacy groups, and a judge without this expansive knowledge would undoubtedly be deemed incompetent by ethical authorities. ${ }^{236}$ However, this specialized knowledge is not specifically mentioned by the $A B A$ Code as part of the ethical obligation to be "competent." While some may argue that this training is included within the "reasonably necessary" language of the $A B A$ Code ${ }^{237}$ this vague approach does not sufficiently encompass the training necessary for juvenile court judges. Indeed, the failure of the Code to acknowledge these expanded training factors as necessary for judicial competence in juvenile court represents a flaw in the ethical scheme. Juvenile court judges seeking clarification of their ethical duty of competence should not have to look to outside training manuals for guidance.

232. In re Baber, 847 S.W.2d 800, 803 (Mo. 1993) (en banc); see also In re Hunter, 823 So.2d 325, 336 (La. 2002) (adopting the In re Baber definition of judicial competence).

233. See generally Juvenile DelinQuency Guidelines, supra note 71.

234. Edwards, supra note 6, at 36; see also Burnett, Sr., supra note 119, at 8 (juvenile court judges "should receive[] specialized training, which is comprehensive and multidisciplinary").

235. Burnett, Sr., supra note 119, at 8 . The use of psychological evidence in juvenile court has been thoroughly considered in the legal literature. See, e.g., Terry Maroney, The False Promise of Adolescent Brain Science in Juvenile Justice, 85 Notre Dame L. Rev. 89 (2009); Elizabeth S. Scott \& Thomas Grisso, Symposium on the Future of Juvenile Court: The Evolution of Adolescence: A Developmental Perspective on Juvenile Justice Reform, 88 J. CRIM. L. \& CRIMINOLOGY 137 (1997).

236. See Edwards, supra note 6, at 36 (1992) (arguing for the need for such training under the chapter title "Retaining Competent Judges").

237. ABA Model Code of Judicial Conduct R. 2.5 cmt. 1 (2007), available at http://www.abanet.org/ judicialethics/ABA_MCJC_approved.pdf. 
Second, the rotating nature of juvenile court assignments in some jurisdictions undermines judicial competence. Julian Mack noted in 1909 that "[i]n some very important jurisdictions the vicious practice is indulged in of assigning a different judge to the juvenile-court work every month or every three months. It is impossible for these judges to gain the necessary experience or to devote the necessary time to the study of new problems."238 Because of the challenging nature of juvenile court, judges in some jurisdictions are asked to serve a minimum term on the juvenile bench. For example, California rules indicate a preference for juvenile court judges to serve a minimum of three years in a juvenile court assignment, with priority given to those who expressed an interest in that court. ${ }^{239}$ Some jurisdictions require five-year terms. ${ }^{240}$

Minimum term requirements reflect an understanding that the "expertise necessary" to be a successful juvenile court judge "can come only from years on the job." ${ }^{241}$ Although a juvenile court judge who serves on the bench for more than two to three years "understands a lot of things by osmosis," not all jurisdictions mandate long-term assignments for juvenile court judges. ${ }^{242}$ As a result, "by the time [judges] understand [what is required], they are gone and someone new is in." 243 The high learning curve in juvenile court, combined with the level of judicial competence expected in a courtroom, requires that judges commit to serving minimum terms on the bench. Of course, judges should take care to avoid any inadvertent biases resulting from too many years on the bench as described in Part III.C.

Third, the Code does not require judges to consider cultural factors as part of their judicial competency obligation. Cultural competency has become increasingly important in juvenile court because children of color are overrepresented in the juvenile justice system. ${ }^{244}$ Indeed, "African American and Latino/a youth experience stereotyping and consequent discrimination at every step of the

238. Julian Mack, The Juvenile Court, 23 HaRv. L. Rev. 104, 119 (1909).

239. CAL. R. Ст., Standard 5.40(a) (2009), available at http://www.courtinfo.ca.gov/rules/index.cfm? title $=$ standards\&linkid $=$ standard5_40.

240. Edwards, supra note 6, at 37.

241. Id. at 36-37 (1992) ("To review the duties and responsibilities . . . is to understand why the juvenile court judge must remain in the position for a substantial number of years in order to be effective.")

242. Telephone Interview with Anonymous California retired Juvenile Court Judge (Jan. 25, 2010).

243. Telephone Interview with Martina Peterson, supra note 98.

244. See Perry Moriearty, Combating the Color-Coded Confinement of Kids: An Equal Protection Remedy, 32 N.Y.U. Rev. L. \& Soc. Change 285, 289 (2008) ("Over the last thirty years, a number of increasingly sophisticated analyses have documented a statistically significant 'race effect' on juvenile justice outcomes.”); Margaret Olesnavage, Disproportionate Representation of Children of Color in the Child Welfare and Juvenile Justice Systems in Michigan, MicH. B. J. 26 (Jan. 2010) ("Youth of color are overrepresented at nearly every point of contact with the juvenile justice system."); Miriam Stohs, Racism in the Juvenile Justice System: A Critical Perspective, 2 WhitTIER J. CHILD \& FAM. Advoc. 97, 109-10 (2003) (discussion of statistics illustrating racial discrepancies at every stage of the juvenile justice process); see also discussion, infra Part V.C. 
[juvenile justice] intake and adjudication process.." ${ }^{245}$ Judges who are culturally insensitive to the needs of children of color risk alienating youth and families in their courtrooms. This lack of understanding could produce unnecessary hostility or resistance in a youth against a judge's authority. ${ }^{246}$ Moreover, a judge's inability to understand the dynamics of a minor's cultural background could result in inappropriate sentencing: A judge who does not appreciate the influence of a youth's culture might not recognize the particular mitigating circumstances that led to the offense, or the proper placement to rehabilitate the youth.

Increasing cultural competence may require additional training for juvenile court judges. As one juvenile court judge explained:

[W]e need more diversity training to alleviate stereotypes and ignorance. We need more relationship training on how to interact with people and communicate better. We need training on the dynamics in the courtroom and how we are perceived by other people. We, as [juvenile court] judges[,] also need training on dealing with certain types of people and their level of functioning. This "real" training isn't something that we are normally taught in workshops that judges are required to attend, but it is vital to address the public in the role that we fill. ${ }^{247}$

Despite the need for cultural competency in juvenile court, the ABA Code acknowledges none of these factors in its definition of "competence." Thus, the ABA should amend the definition of "competence" specifically for juvenile court judges. The expanded comment to Rule 2.5 should provide:

Comment [5]: Juvenile Court judges should serve a minimum of three years on the juvenile court bench. Juvenile court judges must be aware of available community or social service resources for youth. ${ }^{248}$ Juvenile court judges should seek annual or bi-annual training in the areas of juvenile psychological development, family dynamics, and cultural sensitivity.

\section{BIAS, DEMEANOR AND DECORUM}

As the Supreme Court noted in Gault, judges were historically allowed expansive discretion in the disposition of cases in juvenile court. ${ }^{249}$ Judicial discretion is consistent with the rehabilitative purpose of juvenile court, since the "treatment" concept "necessarily entails individual differentiation." ${ }^{250}$ Although juvenile court may be shifting in a more formal and punitive direction, juvenile

245. Anne E. Casey Foundation, Race Matters: Unequal Opportunities for Juvenile Justice 2 (2006), available at http://www.aecf.org/upload/publicationfiles/fact_sheet12.pdf.

246. Juvenile Delinguency Guidelines, supra note 71, at 49.

247. E-mail from Martina Peterson, supra note 109.

248. Proposed amendments are italicized.

249. In re Gault, 387 U.S. 1, 18 (1967).

250. Feld, supra note 9 , at 91. 
court judges still have more discretion than judges in adult criminal or civil court. ${ }^{251}$ Indeed, juvenile court judges recognize that they have an unusual degree of discretion. ${ }^{252}$

Discretion enables juvenile court judges to balance many applicable factors in a juvenile court proceeding. For instance, judges are able to consider factors such as a youthful offender's family history, educational background, and current state of the offender's home life. As a necessary part of the juvenile justice model, discretion enables a judge to sentence juvenile offenders in a way that will serve their best interests.

However, as mentioned above, the discretion granted to judges in juvenile court creates the potential for unethical judicial conduct. In the closed and private world of juvenile court, judicial discretion can "pose[] a threat to both the child's individual liberties and the public welfare." ${ }^{253}$ The corruption of Judge Ciavarella in Pennsylvania, as discussed above, is one highly publicized example of the potential abuse of power in a discretionary court.

Less publicized, but no less significant, are concerns raised by the prevalence of bench trials in juvenile court. In these trials, "[f]ormal rules are virtually non-existent and the judge can consider practically any type of evidence deemed necessary without allowing for cross-examination of witnesses." ${ }^{254}$ In an environment of broad judicial discretion and relaxed evidentiary rules, evidence can be considered that may or may not actually relate to the determination of a youth's guilt or innocence. ${ }^{255}$ A review of case law by Professors Martin Guggenheim and Randy Hertz suggested that juvenile court judges used their discretion to "often convict on evidence so scant that only the most closedminded or misguided juror could think the evidence satisfied the standard of proof beyond a reasonable doubt. ${ }^{, 256}$ Even so, because most appellate courts rarely reverse bench trial convictions, juveniles were at risk of excessive sentences. ${ }^{257}$

251. See Stohs, supra note 244, at 104 ("In spite of the shift to more formal and punitive proceedings, the modern juvenile justice system continues to function with greater informality and discretion, relative to the adult system, at every step of the process."); see also Harris, supra note 69, at 390 ("[D]espite the introduction of formal legal criteria to guide judicial decisions, judges still have some discretion in the ways that they characterize both offenses and offenders in their sentencing decisions, even if the discretion is somewhat abridged.").

252. Interview with the Honorable Donna Hitchens, supra note 106.

253. Drizin \& Luloff, supra note 31 , at 319.

254. Stohs, supra note 244 , at 107.

255. Id. at 106 (citing BARry Krisberg \& JAmes F. Austin, Reinventing Juvenile Justice at 79).

256. Guggenheim \& Hertz, supra note 45, at 564 (providing "examples of cases in which a juvenile court judge convicted an alleged delinquent on evidence that an appellate court easily found to be insufficient"). For example, in a Washington case cited by Professors Guggenheim and Hertz, a "trial judge convicted a juvenile of aiding and abetting animal cruelty in the second degree based solely on evidence "that he was present and giggled while another boy threw a pigeon into a fountain."” Id. at 565 (internal citations omitted).

257. Id. at 566-67 ("[A] review of the cases in which insufficiency claims failed readily reveals numerous instances in which the vast majority of 'reasonable factfinders' would have acquitted."). 
Of course, the ABA Code of Judicial Conduct forbids bias on the bench. Judges are advised to perform their duties without bias, prejudice or harassment based upon a variety of factors: race, sex, gender, religion, national origin, ethnicity, disability, age, sexual orientation, marital status, socio-economic status, and political affiliation. ${ }^{258}$ The ABA identified helpful examples of the manifestation of bias or prejudice, such as epithets, slurs, demeaning nicknames, and "threatening, intimidating, or hostile acts." 259

While the ABA's prohibition against bias is useful, it does not acknowledge the distinctive risks of bias that exist in juvenile court. Juvenile court's "unbridled" 260 discretion and informal procedures present a heightened possibility of judicial bias, since discretion can constitute "a euphemism for idiosyncratic judicial subjectivity." ${ }^{261}$ Not all cases of judicial bias are deliberate; for example, as discussed above, bias can inadvertently result from years of experience on the bench. However, a risk exists that judges will decide cases or sentence youth differently based on their own personal preferences or prejudices.

A biased judge may make determinations based on "extraneous personal characteristics for which [the youth] bear no responsibility." 262 In one illustrative example, a juvenile court judge in Tennessee was publicly censured for his habit of ruling against immigrant juveniles "based solely on the real or perceived immigration status" of the children or their parents. ${ }^{263}$ In a formal Letter of Reprimand, the Court of the Judiciary noted that this judge's actions displayed "a perceived predetermination as to Hispanic individuals appearing before [him]."264

Statistical evidence demonstrating racial disparities throughout the juvenile justice system make bias concerns all the more troubling. ${ }^{265}$ For example, African American adolescents, particularly males with mental health issues, are more likely to be referred to a juvenile delinquency court than a treatment

258. ABA Model Code of Judicial Conduct R. 2.3(A)-(B) (2007), available at http://www.abanet.org/ judicialethics/ABA_MCJC_approved.pdf.

259. ABA Model Code of Judicial Conduct R. 2.3 cmt. 2 (2007), available at http://www.abanet.org/ judicialethics/ABA_MCJC_approved.pdf.

260. In re Gault, 387 U.S. 1, 18 (1967).

261. Feld, supra note 9, at 91.

262. Id. at $91-92$.

263. John Lamb, Formal Rreprimand for Dickson County Juvenile Court Judge who Overemphasized Immigration, HiSPANIC NASHVILlE (May 29, 2008, 6:24 AM), available at http://www.hispanicnashville.com/ 2008/05/formal-reprimand-for-dickson-county.html.

264. Formal Letter of Reprimand from the Honorable Don R. Ash, Presiding Judge, Tennessee Court of the Judiciary, to the Honorable A. Andrew Jackson, Dickson Cnty. Gen. Sessions Judge, (May 16, 2008), available at http://www.tba2.org/tbatoday/news/2008/judicialreprimand_051608.pdf. For additional cases of bias on the juvenile court bench, see In re Joseph P. Esworthy, 1990 WL 656123 (N.Y. Comm'n Judicial Conduct 1990) (juvenile court judge removed from bench for making inappropriate comments during a juvenile delinquency proceeding); In re Raymond E. Aldrickh, Jr., 1982 WL 196852 (N.Y. Comm'n Judicial Conduct 1982) (judge removed from juvenile court bench for using "profane, improper and menacing language," making "inappropriate racial references," and "otherwise [behaving] in an inappropriate and degrading manner").

265. See supra note 244. 
system. ${ }^{266}$ In 2007-2008, African American students in Florida were two and a half times more likely than white students to be arrested and referred to the juvenile justice system. ${ }^{267}$ Mexican Americans and other immigrant groups are more likely to suffer from "treatable, yet untreated" mental illnesses, a major cause of the types of behavior landing youth in delinquency court proceedings. ${ }^{268}$ Moreover, Latino students in Colorado were fifty percent more likely than white students to be referred to law enforcement in 2006-2008. ${ }^{269}$ Juvenile court judges thus have great discretion in a system with a disproportionate representation of youth of color, which could allow personal racial bias or prejudice to have an enhanced role in adjudications.

Gender bias is also a concern, especially given the rising involvement of girls in the juvenile justice system. The arrest rates for girls increased thirty-five percent between 1980 and 2000, while the arrest rates for boys decreased. ${ }^{270}$ Indeed, gender bias is a "principal culprit in girls' continued and growing presence" in the juvenile justice system. ${ }^{271}$ Bias on the part of judges can "extend[] in both directions"; some girls may be able to "sweet-talk" judges in an attempt to "manipulate the system," while others may be treated more harshly. ${ }^{272}$

Moreover, as noted earlier, the Harris study found that some judges with high career ambitions are interested in being promoted beyond the juvenile court. ${ }^{273}$ Some judges may hold a bias toward the prosecution in order to curry favor for the fulfillment of their own aspirations or to prevent the appearance of being "soft on crime." 274 Or in jurisdictions with a powerful public defender office, judges may decide cases in favor of the defense for the same reason. Either way, judges in juvenile court have more discretion than judges in adult courts to act on such biases.

As an integral part of juvenile court proceedings, judicial discretion should not be eliminated. However, although judicial bias is difficult to quantify, the possibility of bias in this court with broad judicial discretion should be more thoroughly examined. Unlike adult courts, the decisions of juvenile court judges

266. JuVEnile DelinQuency Guidelines, supra note 71, at 49.

267. Advancement Project, Test, Punish, and Push Out: How “Zero Tolerance” and High-Stakes Testing Funnel Youth Into the School-to-Prison Pipeline 19 (Jan. 2010), available at http:// www.advancementproject.org/sites/default/files/publications/01-EducationReport-2009v8-HiRes.pdf (internal citations omitted).

268. JuVEnILE DelinQuency Guidelines, supra note 71, at 50.

269. See Advancement Project, supra note 267, at 19.

270. Kim Taylor-Thompson, Girl Talk_Examining Racial and Gender Lines in Juvenile Justice, 6 NEV. L.J. 1137, 1137 (2006).

271. Id. at 1138 .

272. Jennifer Thibodeau, Note, Sugar and Spice and Everything Nice: Female Juvenile Delinquency and Gender Bias in Punishment and Behavior in Juvenile Courts, 8 WM. \& MARY J. WoMEN \& L. 489, 504-05 (2002).

273. Harris, supra note 69, at 404.

274. Guggenheim \& Hertz, supra note 45, at 569-70. 
impact a particularly vulnerable population and can irreparably determine the course of a young litigant's future.

Admittedly, any code of ethics is limited in its ability to truly regulate bias on the bench. Indeed, it may be difficult for ethical authorities to eliminate bias entirely in any courtroom, including juvenile court. Judges themselves may be in denial about their personal biases. Hence, formal rules prohibiting bias are not sufficient to address this problem; other procedural steps are necessary to ensure unbiased behavior on the bench. Although a full examination of procedural actions is beyond the scope of this Article, these measures could include increased monitoring of judges and enforcement of rules through disciplinary procedures.

To counteract the difficulties inherent in identifying and reducing bias, the $A B A$ Code may have stronger influence in a more measurable area: judicial behavior. The Code already mandates proper judicial demeanor and decorum. ${ }^{275}$ Yet the vague provisions of the Code, designed to apply to any person in a judicial capacity, do not specifically acknowledge the importance of judicial demeanor in specialized courts with vulnerable populations. Accordingly, the ABA should amend the Code of Conduct's provisions regarding judicial demeanor and decorum in the context of juvenile court. ${ }^{276}$

Judicial demeanor is receiving renewed attention in other areas. For example, in response to complaints of judicial bias and incompetence on the immigration bench, Attorney General Alberto Gonzalez ordered performance evaluations in 2006 that included an assessment as to whether new judicial appointees "possess[] the appropriate judicial temperament ... for the job." ${ }^{277}$ The Attorney General's order suggested that "temperament" was an important element of judicial competence for immigration judges. ${ }^{278}$ Similarly, applicants to the juvenile court delinquency bench could be screened to ensure they have the proper temperament to work directly with litigants in their specialized courts.

Juvenile court judges clearly have to walk a line between "reprimanding parent and warm embracing judge," depending on each individual case. ${ }^{279}$ Unlike civil court, in which there is "no expressed emotion" by the judge, many judges

275. ABA Model Code of Judicial Conduct R. 2.8 (2007), available at http://www.abanet.org/judicialethics/ ABA_MCJC_approved.pdf.

276. Rozier E. Sanchez Judicial Education Center of New Mexico (JEC), Judicial Ethics Handbook R. 7-310, available at http://jec.unm.edu/resources/judicial_handbook/ethics/ethics07.htm ("Demeanor and decorum are no less important in the courts of limited jurisdiction than in the general jurisdiction courts.").

277. Press Release, U.S. Dep't of Justice, Attorney General Alberto R. Gonzales Outlines Reforms for Immigration Courts and Board of Immigration Appeals (Aug. 9, 2006), available at http://www.usdoj.gov/opa/ pr/2006/August/06_ag_520.html. For an analysis of judicial competence in the context of immigration judges, see Benedetto, supra note 66.

278. Benedetto, supra note 277 , at 507.

279. Interview with the Honorable Donna Hitchens, supra note 106 (Judges can sometimes be "Dr. Jekyll and Mr. Hyde" from one case to the next.). 
believe "emotion is needed in juvenile court." ${ }^{280}$ One juvenile court judge reported that she has a "completely different demeanor in a juvenile case" for several reasons. ${ }^{281}$ Echoing the Supreme Court in Roper, this judge recognizes that a child's "cognitive reasoning" does not develop until his or her late teens. ${ }^{28}$ In addition, because "kids are scared," speaking in a "calm tone of voice" will reduce the likelihood of tantrums or frustration in her courtroom. ${ }^{283}$ Another judge noted that he takes care when there are siblings in his courtroom by "making eye contact with all siblings equally so they don't think you are treating them unequally." 284

Improper judicial demeanor can have a substantial effect on court participants. An evaluation prepared for the Idaho Supreme Court Child Protection Committee found that youth in juvenile court proceedings did not feel they were taken seriously in court, and did not feel they were engaged in the court process. ${ }^{285}$ The youth reported that their experience in court 'was 'scary,' that they felt 'stressed out,' or that 'it was embarrassing to talk in front of all those people."' ${ }^{286}$ The youth recommended that they should be treated with more "respect and courtesy" in court. ${ }^{287}$ These findings suggest that more attention should be paid to the actions of judges during juvenile court proceedings.

The ABA Code could provide the catalyst for an increased focus on judicial behavior by considering broader components of demeanor and decorum in the context of juvenile court judges.

The amended Code should read:

Rule 2.8(B)(1): A juvenile court judge should consider the varied levels of cognitive development in youth while addressing litigants. Juvenile court judges must maintain a respectful demeanor and calm temperament with youth offenders, their families, and victims at all times during juvenile court proceedings. ${ }^{288}$

\section{CONCLUSION}

Those who choose to sit on the juvenile court bench accept a challenging role in a complicated court. The purpose of juvenile court may be moving toward a

\footnotetext{
280. Id.

281. Telephone Interview with Martina Peterson, supra note 98.

282. Id.

283. Id.

284. Telephone Interview with Anonymous Missouri Juvenile Court Commissioner (Jan. 21, 2010).

285. See Idaho Supreme Ct. Child Protection Comm., Involving Foster Youth and Foster Parents in Child Protection Proceedings: A Process Evaluation of Idaho Juvenile Rule 40, 3 (2009), available at http://www.isc.idaho.gov/Involving\%20Foster\%20Youth\%20and\%20Foster\%20Parents\%20in\%20Child\%20 Protection\%20Proceedings.pdf. The report focused on dependency proceedings in five Idaho counties. Id. at 1. 286. Id. at 44.

287. Id. at 40 .

288. Proposed amendments are italicized.
} 
more punitive model, but the rehabilitative nature of the court is still prevalent. This purpose sets the court apart from adult criminal court. Similarly, although some constitutional protections exist for juvenile offenders, procedures in juvenile court remain more informal and more dependent on judicial discretion. Delinquency judges retain the ability to place youth in more flexible placements than those available to adult offenders. Juvenile court judges are expected to assume a greater role as educators in the community. In sum, juvenile court is unique.

One would never recognize, however, the unique nature of juvenile court by reviewing the ethical guidelines applied to juvenile court judges. The ABA Code of Judicial Conduct, intended to apply to anyone performing judicial functions, ignores the distinct challenges faced by adjudicators in juvenile court. ${ }^{289}$ Juvenile court judges should not be forced to consult multiple training manuals from various sources when confronted with an ethical challenge. Rather, the ABA Code should be amended to reflect the needs of these judges.

This revision process does not necessitate an amendment of the entire Code; alterations of provisions that are particularly relevant to juvenile court would be a cost-effective and simple way to provide additional guidance. To that end, this article recommends modifications to the provisions governing ex parte communications, judicial competence, and judicial demeanor and decorum. By clarifying the ethical standards for juvenile court judges, these amendments also acknowledge the attempts of juvenile court founders to create a special system for the adjudication of youthful offenders.

The responsibility to ensure an ethical bench in juvenile court lies within every member of society. As Judge Julian Mack noted more than one hundred years ago, the work of this court "demands the united and aroused efforts of the whole community, bent on keeping children from becoming criminals, determined that those who are treading the downward path shall be halted and led back." 290 Ultimately, the implementation of ethical guidelines tailored for this specialized court will reinforce judges' abilities to determine the best outcomes for our society's youth.

289. See generally ABA Model CODE of Judicial Conduct, application I.B (2007), available at http://www.abanet.org/judicialethics/ABA_MCJC_approved.pdf.

290. Julian Mack, The Juvenile Court, 23 Harv. L. REv. 104, 122 (1909). 